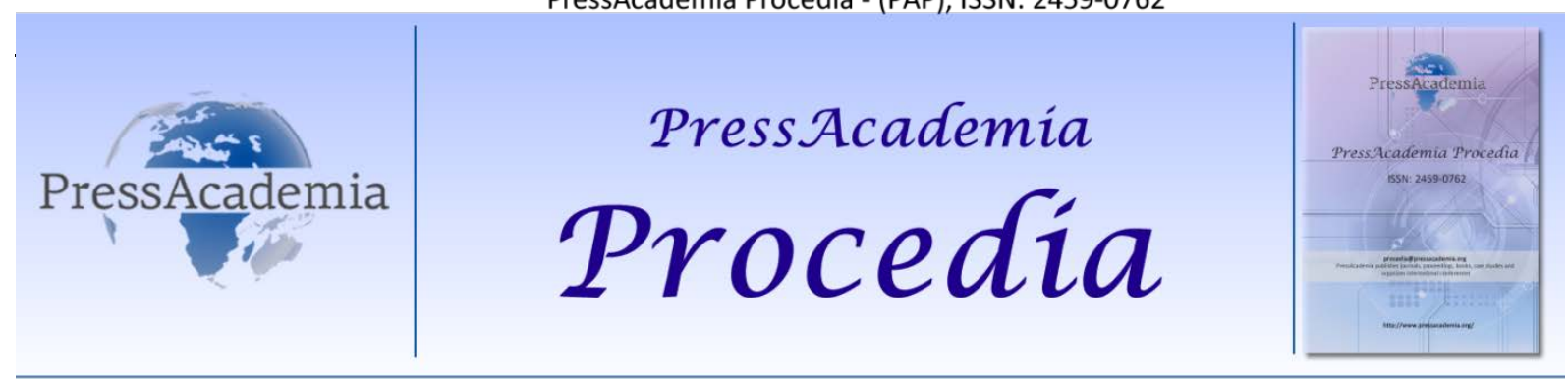

Global Business Research Congress (GBRC), May 26-27, 2016, Istanbul, Turkey.

\title{
TRANSFER OF MANAGEMENT AUTHORITY IN JOINT STOCK COMPANY CONTENT ORGANIZATION REGULATION
}

DOI: 10.17261/Pressacademia.2016118680

\author{
Abdulkadir Bulut \\ Selçuk Üniversitesi, abdulkadirbulut@gmail.com
}

\begin{abstract}
Management and representation powers belong to the board of directors in joint-stock company. In Turkish Commercial Code, the board of directors can appoint commercial representatives and commercial agents and the board members and third parties in charge of management held liable for protection of the company's interests. The board may transfer all powers excluding non-transferable and nongive up powers. However, some conditions are searched for. These conditions: there must be a provision in the articles of association, and in accordance with the law internal directive must be preparad and approved. In this study we will discuss that tranfer to management via organization regulation.
\end{abstract}

Keywords: Joint-stock company, management, representation, organization regulation, transfer of authority. JEL Codes: K22

\section{TAŞIMA KAPLARININ ELLE YERLEŞTIRILMESINDE ZORLANMAYA NEDEN OLAN ÇALIŞMA DURUŞLARININ ANALIZI}

\section{ÖZET}

Anonim şirketlerde yönetim ve temsil yetkisi yönetim kurulundadır. Türk Ticaret Kanunu'nda yönetim kurulu ticari temsilci ve ticari vekiller atayabilir, yönetim kurulu üyeleri ve yönetimden sorumlu üçüncü kişiler, şirketin çıkarlarının korunmasından sorumlu tutulur. Yönetim kurulu devredilemeyen ve vazgeçilemeyen yetkileri hariç bütün yetkilerini devredebilir. Ancak bunun için bazı şartlar aranmaktadır. Bu şartlar: esas sözleşmede bir hüküm olmalı, Kanuna uygun olarak iç yönerge hazırlanmalı ve onaylanmalıdır. Bu çalışmada, iç yönerge ile yönetim yetkisinin devrini ele alacağız.

Anahtar Kelimeler: Anonim şirket, yönetim, temsil, iç yönerge, yetki devri.

JEL Kodu: K22

\section{GiRiş}

Anonim şirketlerde korporatif bir yapı söz konusudur. Şirketin yönetim ve karar organı kanunda belirtilmiştir. Anonim şirketlerde yönetim organı, yönetim kuruludur (YK). YK, kanunen şirketin yönetim hak ve görevine sahiptir. Ancak YK, bu hak ve görevini, üyeleri arasında bölebilecek ve hatta üçüncü kişilere de devredebilecektir (m. 367). YK bu işlemi, esas sözleşmeye konulacak bir hükümle kendisinin düzenleyeceği bir iç yönerge ile yapabilecektir (m.367,1). Yönetim yetkisini tamamen veya kısmen devrine yetkili olan YK, yönetim ve temsil yetkisini devrederken belirli şartlara ve sınırlamalara uymak zorundadır. En önemli sınırlama YK'nın m. 375'te 
düzenlenen görev ve yetkileridir. TK m. 375'te YK'nın devredilmez ve vazgeçilmez görev ve yetkileri düzenlenmiştir. YK bu görev ve yetkiler dışındaki görev ve yetkilerini devredebilecektir.

Yönetime ait hukuki işler bir kişiye, mali işler bir başka kişiye, üretim işleri de bir başka kimseye devredilebilir. Ancak yönetimin devrinin kapsamı, Kanun, esas sözleşme ve iç yönerge kapsamında belirlenecektir. Yönetim, YK üyeleri arasından bir/birkaç kişiye veya üçüncü kişilere devredilirken, bu kişilerin görev tanımlaması yapılmalıdır. Bu husus yöneticilerin sorumluluk rejimi açısından çok önemlidir. Yönetimin devri, m. 367,1 çerçevesinde yönetim işlerinin tamamının veya bir kısmının YK üyelerinden birine veya bir kaçına veya üçüncü kişilere $^{1}$ bırakılmasıdır $^{2}$. Bu halde kendisine görev devredilmeyen YK üyeleri şu iki istisnai hal dışında sorumluluktan kurtulur: illk olarak, YK'nın devredilmez ve vazgeçilmez görev ve yetkilerine giren konularda yetki devri yapılmışsa; ikinci olarak da, yetki devri yapılan kişinin seçiminde ve gözetiminde ${ }^{3}$ makul derecede özen gösterilmemişse YK'nın sorumluluğu devam etmektedir ${ }^{4}$.

Anonim şirketlerde temsil yetkisi de kural olarak YK'ya aittir. YK iç ilişkide ortaklara karşı, dış ilişkide üçüncü kişilere karşı şirketi temsil eder. Temsil, şirket adına üçüncü kişilerle şirketin işletme konusuna ${ }^{5}$ giren hukuki işlemleri yapmak, şirketi üçüncü kişilere karşı hak sahibi kılmak veya yükümlülük altına sokmaktır ${ }^{6}$. Temsil anonim şirketlerde, ortaklar açısından bir hak ve borç doğurmadığı halde, YK üyeleri için hem hak hem de borçtur. Yeni TK, temsil ve yönetim yetkisini kesin bir şekilde birbirinden ayırmıştır ${ }^{7}$. Aynı şekilde eski kanundan farklı olarak yönetim ve temsil görev ve yetkilerinin ayrı ayrı devri mümkün kılınmıştır ${ }^{8}$. Esas sözleşmede aksi öngörülmemişse veya YK tek kişiden oluşmuyorsa, temsil yetkisi çift imza ile kullanılmak üzere YK'ya aittir (m. 370,1). TK mehaz kanundan (OR m. 718) farklı olarak temsil yetkisinin iç yönerge ile devrine izin vermemiştir ${ }^{9}$. Sayılı Torba Kanun Ile TTK m. 371'e Eklenen Yedinci Fıkraya ilişsin Değerlendirmeler", www.arslanlibilisimarsivi.com-01.10.2015, s. 6.

2 ÜÇıŞıK, Güzin/ ÇELiK, Aydın, Anonim Ortaklıklar Hukuku, I. Cilt, Ankara 2013, s. 431; TEKiNALP, Ünal, Yeni Anonim ve Limited Ortaklıklar Ille Tek Kişi Ortaklığın Esasları, İstanbul 2012, (Tek Kişi Ortaklık), s. 138.

KIRCA, İsmail/ŞEHiRALi ÇELiK Feyzan Hayal/ MANAVGAT, Çağlar, Anonim Şirketler Hukuku Cilt 1, Ankara 2013, s. 613; TEKinALP, Ünal, Sermaye Ortaklıklarının Yeni Hukuku, İstanbul 2013, (Sermaye Ortaklıkları), s. 214.

BAHTiYAR, Mehmet, Ortaklıklar Hukuku, 8. Bası, İstanbul 2014, s. 211

5 Yeni TK'da ultra vires kaldırılmış, YK veya yöneticilerin üçüncü kişilerle yapmış olduğu işletme konusu dışındaki işlemlerle de şirket bağlı hale gelmiştir. Ultra vires ile ilgili açıklamalar için bkz. Gerekçe m. 125; TEKiNALP, Tek Kişi Ortaklık, s.143; PULAŞLI, Hasan, 6102 sayılı Türk Ticaret Kanununa Göre Şirketler Hukuku Şerhi, C. I, Adalet Yayınevi, Ankara 2011, (Cilt I), s. 1017; KARAHAN, Sami, Şirketler Hukuku, Güncellenmiş 2. Baskı, Konya 2013, s. 396; BOZKURT, Tamer, Şirketler ve Kooperatifler Hukuku, 6. Baskı, i̇stanbul 2012, s. 198.

6 AKDAĞ GÜNEY, 6552 s. Kanun, s. 4.

7 AKDAĞ GÜNEY, 6552 s. Kanun, s. 4

8 CEYLAN, Nurgül, "Anonim Şirketlerde Yönetim ve Temsil Yetkisinin Devrinin Anlamı, Sonuçları ve TTK m. 371 f.7 Ile Karşılaş̧ırılması", TNB Hukuk Dergisi, Ankara 2015, S. 1, s. 21. 6335 s. Kanun ve 6552 s. Kanun değişikliklerinden sonra temsil yetkisinin devrinde de yönetimin devrine ilişkin usul ve esaslar uygulanmaktadır. Ayrıntılı bilgi için bkz. ÖZDAMAR, Mehmet, "6552 Sayılı Kanun ile TTK'da Yapılan Değişiklikler Çerçevesinde Anonim Şirketin Temsili", GÜHFD, C. XVIII, Y. 2014, S. 3-4, s. 153. Pulaşlı, TK m. 370,2'de düzenlenen temsil yetkisinin bir veya birden fazla üyeye veya üçüncü kişilere devredebilmesinde hareketle yönetim yetkisinin devri ile temsil yetkisinin devrinin birbirinden farklı olduğunu savunmaktadır. PULAȘLI, Hasan, 6102 Sayılı Türk Ticaret Kanununa Göre Yeni Şirketler Hukuku Genel Esaslar, Adalet Yayınevi, Ankara 2012, (Genel Esaslar), s. 423. TK m. 367'nin sadece yönetimin kısmen veya tamamen devrinde görev devredilen üyelere (icracı), diğerleri icracı olmayan üyeler olarak anılması söz konusu değildir. Kanaatimizce de temsil yetkisinin devri ile yönetim yetkisinin devri birbirinden farklıdır. Ancak hem temsil yetkisinin devrinde hem de yönetim yetkisinin devrinde benzer usul ve esaslar uygulanacaktır. Karşı görüş için bkz. DOĞAN, Fatih Beşir, Anonim Şirket Yönetim Kurulunun Organizasyonu ve Yönetim Yetkisinin Devri, 2. Baskı, ìstanbul 2011, s. 114 ve 117 . Karahan da 367'deki yönetim yetkisinin bölünmesi ve devri esaslarının temsil açısından da geçerli olduğunu savunmuştur. Bkz. KARAHAN, s. 413. Nitekim uygulamada iç yönergelerin yönetim için ayrı temsil için ayrı şekilde düzenlendiğini ve temsil hükümlerinin yer aldığı iç yönergelerin ticaret siciline tescil edildiği görülmektedir.

9 AKDAĞ GÜNEY, 6552 s. Kanun, s. 5 
6552 s. Kanun ${ }^{10}$ m. 131 ile TK'nın 371. maddesine 7. fıkra eklenmiş ve bu fıkra ile temsil yetkisinin iç yönerge ile devredilmesine kesin olarak kapı kapanmıştır ${ }^{11}$. Ancak BAHTiYAR ${ }^{12}$ yönetimin devrine ilişkin m. 367 'nin temsil yetkisinin devrine de uygulanacağını belirtmiştir. Nitekim 371,1 ile yapılan değişiklik bu görüşü desteklemektedir. Şunu da önemle belirtmek gerekir ki, sadece yönetimin bırakıldığı kişi murahhas değildir ${ }^{13}$. Çünkü murahhaslık hem yönetim hem de temsil yetkisiyle görevli ve yetkili kişiler için kullanılmaktadır.

Çalışmamızda anonim şirketlerde iç yönerge kapsamında yönetim yetkisinin devredilmesi ile bu şekilde yapılacak devrin hukuki sonuçları incelenecektir. Ayrıca yer yer temsil yetkisinin devrine ilişkin hususlara da yer vereceğiz.

\section{YÖNETIM KAVRAMI VE YÖNETIM KURULU}

Yönetim kelimesi Türk Dil Kurumu sözlüğünde “yönetmek işi, çekip çevirmek, idare” olarak tanımlanmıştır ${ }^{14}$. Yönetim, şirketler hukukunda şirketin iç işleriyle ilgili olup içe dönük işlemleri ifade eder ${ }^{15}$.

Yönetim, şirketin işletme konusunun gerçekleştirilmesi için gerekli olan her çeşit iş ve işlemler hakkında karar alınması olarak tanımlanabilir ${ }^{16}$. Yönetim ilk olarak, YK'ya verilen görevi ifade eder ${ }^{17}$. İkinci olarak yönetim, anonim şirketin yönetim işlevini yerine getiren örgütün adıdır ${ }^{18}$. Her anonim şirketin bir yönetim örgütü mevcuttur. Yönetim işlevi bir bütün halinde YK'nın görevinin bir parçasıdır. YK, hem yönetimin görevlisi hem de yönetimin başıdır. TK m. 365'te belirtilen "anonim şirket, yönetim kurulu tarafından yönetilir" hükmü ile, hem anonim şirketin işletme konusunun elde edilmesi hem de organizasyonun yönetilmesini kastetmiştir ${ }^{19}$. Şirketin işletme konusu dışındaki YK işlemleri de şirketi bağlayacaktır (m. 370) ${ }^{20}$. Bu açıdan GK'nın görev ve yetkisine girmeyen ve şirketin dış denetimine ilişkin olmayan, şirket ortakları ve üçüncü kişilerle yapılan her türlü YK işlemi yönetim işlemidir.

Yönetim, şirket iş ve işlemlerinin yürütülmesi ile şirket ile ortakları arasındaki ilişkileri düzenleyen Kanun ve esas sözleşme hükümlerinin öngördüğü görev ve yetkileri de kapsar ${ }^{21}$. Şirketin iş ve işlemlerine; gündelik işlerin yapılması, memur ve müstahdemlerin atanması, ticari temsilcilerin atanması ve azli, defterlerin tutulması, yazışmaların yürütülmesi örnek gösterilebilir ${ }^{22}$.

\subsection{Yönetim Kurulunun Organizasyonu}

YK'nın organizasyonu, şirketin etkin ve verimli çalışması ve amacına ulaşması açısından çok önemlidir ${ }^{23}$. Anonim şirketlerde YK'nın organizasyonunu açıklayabilmek için öncelikle organizasyon modelleri ve organizasyon özgürlüğü kavramını ele almak gerekir.

İş Kanunu ve Bazı Kanun Hükmünde Kararnamelerde Değişiklik Yapılması İle Bazı Alacakların Yeniden Yapılandırılmasına Dair Kanun için bkz. RG: 11.09.2014, S. 29116 (mükerrer).

11 AKDAĞ GÜNEY, 6552 s. Kanun, s. 5.

12 BAHTIYAR, s. 213.

13 TEKinALP, Tek Kişi Ortaklık, s. 138.

${ }^{14}$ Tanım için bkz. http://www.tdk.gov.tr/index.php?option=com_gts\&arama=gts\&guid=TDK.GTS.549acd49c9fa42.99005062-17.10.2015. 


\subsubsection{Organizasyon Modelleri}

Fiil ehliyeti, kendi fiilleriyle hak sahibi olup borç altına girebilmeyi ifade eder (TMK m. 9). Fiil ehliyeti, tüzel kişilerde kanuna ve kuruluş belgelerine göre gerekli organlara sahip olmakla kazanılır (TMK m.49). Tüzel kişiler iradelerini organları aracılığıyla oluşturur ve açıklar (TMK m.50,1). Organlar, hukuki işlemleri ve diğer bütün fiilleriyle tüzel kişiyi borç altına sokarlar (TMK m.50,2). Anonim şirket bir tüzel kişilik ve YK da organ olduğuna göre, YK'nın yapmış olduğu işlemler anonim şirketi bağlayacaktır. Ancak YK birden fazla kişiden oluşuyorsa, kimin imzasıyla ${ }^{24}$ şirketin bağlı olacağı Kanun, esas sözleşme ve YK'nın yönetim organizasyonunu açıklayan bir metin sayesinde belirginlik kazanacaktır. Anonim şirketin organizasyonu kapsamında yönetim ve gözetim yetkilerinin hangi organ tarafından kullanılacağı ve yönetim yetkilerini nasıl ve ne şekilde devredileceği belli bir yönetim modeline göre belirlenir ${ }^{25}$.

Anonim şirketler hukukunda yönetim fonksiyonu ile temsil yetkisinin ortaklık organizasyonu içinde dağılımına ilişkin özellikle tekli (monist) ve ikili (dualist) sistem olmak üzere iki sistemden bahsetmek gerekir ${ }^{26}$. Kuvvetler birliği sistemi ilkesine dayanan monist sistemde yönetim ve gözetim yetkisi yönetim kurulu denilen tek bir organa aittir ${ }^{27}$. Yönetim kurulu şirketin işletme politikasını belirleyen bu yönde kararlar alıp uygulayan ve bu tür faaliyetlerin gözetimini de yerine getiren organdır. Bu sistemde YK, kurul-organ olarak çalışır. Ancak günümüzde kurul organ yapısı terk edilmeye başlanmıştır. İsviçre'de kurul organ istisnai hal almıştır ${ }^{28}$. Kurul organ yapısının bir takım dezavantajları vardır. Organın toplanması ile ilgili sorunlar, karar alma sürecinde oluşabilecek ihtilaflar ve zamandan tasarruf etme amacı örnek gösterilebilir ${ }^{29}$. Türk hukukunda ve i̇sviçre hukukunda bu sistemin uygulandığı görülmektedir ${ }^{30}$.

İkili sisteme baktığımızda, fonksiyonel anlamda işlerin yürütülmesi birbirinden kesin olarak ayrılmış iki organ bulunmaktadır $^{31}$. Almanya'da uygulanan yönetici kurul ve gözetim kurulu yapısı bu sisteme en güzel örnektir. Bu sistemde şirket yönetimi, şirket işlerinin yürütülmesi ve şirketin temsili görevi münhasırın yönetici kurula aittir. Yönetici kurul bu görevi kendi sorumluluğu altında kurul olarak yürütür: operasyonel ve stratejik kararları alma, kısa ve uzun vadeli hedefler tespit etme, organizasyon ve finansal yapıyla ilgili planlar yapma ve uygulama, yatırım ve kar dağıtım politikasını belirleme işlerini yapar ${ }^{32}$. Bu sistemde yönetici kurulun en az bir üyesinin olması zorunludur ${ }^{33}$. Birden fazla üyeye sahip olabilmesi için esas sözleşmede hüküm bulunmalıdır ${ }^{34}$. Eğer yönetici kurulda şirket çalışanlarını temsil eden bir yönetici varsa yönetici kurul en az iki üyeden oluşmak zorundadır $^{35}$. Yönetici kurul üyeleri, gözetim kurulu tarafından en fazla beş yıl için seçilir (APOK 84/I). Görev süreleri dolmadan bir yıl önce ikinci bir beş yıl için tekrar yönetici kurul üyesi seçilebilir. Gözetim kurulu önemli bir sebebin bulunması halinde yönetici kurul üyelerini görevden alabilir ${ }^{36}$. Yönetici kurul üyesini atama yetkisi hüküm de olmadığına göre, çekleri keşide eden kişinin tek başına şirketi temsil ve ilzam yetkisinin bulunmadığı kabul edilmelidir". Yargıtay 11. HD, T. 06.05.1999, E. 1998/8748, K. 1999/3729 (www.kazancı.com-21.09.2015). Katılımı, Ankara 2008, s. 47.

HACIMAHMUTOĞLU, s.48. 
ve görevden alma yetkisi gözetim kurulunun devredilmez yetkisidir ${ }^{37}$. Gözetim kurulu üyeleri, şirket genel kurulu tarafından seçilen gerçek kişilerden oluşur ${ }^{38}$. Ancak belirli sayıda işçi çalıştıran şirketlerde gözetim kuruluna iş̧̧iler ve iş̧̧i örgütleri de üye seçebilmektedir ${ }^{39}$. Bu sayede işçiler ile şirket arasında sıkı bir bağ kurulmakta ve şirketin daha verimli çalışması sağlanmaktadır ${ }^{40}$.

Kanaatimizce dualist sistemin Türk hukukunda uygulanması mümkün değildir. Türk hukukunda şirketlerin daha hızlı karar alma ve faaliyetlerini daha istikrarlı bir şekilde yürütme amacı bu sisteme karşı çekince oluşturmaktadır. Almanya'da bu sistemin uygulanmasında iş̧̧i sendikalarının etkili olduğu görülmektedir. Günümüz Türkiye'sinde sendikalaşmadan dolayı işçi çıkarılmalarının hala çok sık görüldüğünü söyleyebiliriz. Bu sistem Almanya'da da eleştirilmektedir.

TK m. 367 ile 370,2 hükmünün öngördüğü sistem, ABD'de uygulanan yönetim hakkı olan (executive) ve olmayan (non-executive) YK üyeleri ayrımına daha yakındır ${ }^{41}$.

Yeni TK, şirket esas sözleşmesinde hüküm bulunması şartı ile -bir örgütlenme yönergesine göre- yönetimin kısmen veya tamamen devrini öngörerek, anonim şirket yönetim kurulunun yapısını bir anlamda Amerikan kurul sistemine uygun hale getirmiş ve Eski TK'da zaten mevcut bulunan sistemi geliştirmiştir. Yeni sistem, bu yönüyle, yürütme yetkisini haiz olan ve olmayan (executive/non-executive) yönetim kurulu üyesi ayrımının uygulanmasına müsaittir. Bu düzenleme, Alman yönetim kurulu/gözetim kurulu ve Fransız genel müdürün şirket başkanı olduğu (Président Directeur Général) sisteme de olanak vermektedir ${ }^{42}$.

Yeni TK'da yönetim kurulu yanında ondan tamamen bağımsız, "yönetim" diye adlandırılan bir organ oluşturulmamıştır. YK ile "yönetim" arasında kesin bir ayrım bulunduğu anlayışı da reddedilmiştir. Sadece şirketin işletme konusunun elde edilebilmesi için gerekli tüm kararların alınması hakkının, yani bir iç ilişki hakkı olan yönetimin kısmen veya tamamen devrine imkân verilmiştir ${ }^{43}$.

\subsubsection{Organizasyon Özgürlüğü}

Anonim şirketlerde yönetim ve temsil yetkisi, devredilmediği sürece YK'ya aittir (m. 367,2). YK, GK'nın yetkisine girmeyen konularda karar almaya ve şirketi yönetmeye yetkilidir. Şirketin YK tarafından, kurul olarak yönetilmesi küçük AŞ’ler için ideal bir sistem olarak görülmesine rağmen, her anonim şirkette başarı sağlandığı söylenemez ${ }^{44}$. Bu sebeple YK'nın her şirketin intiyacına göre organize edilmesi gerekir. Öncelikle şirket yönetimin emredici hükümlere göre organize edilmesi şirketin pay sahipleri ve alacaklıları bakımından bazı avantajlar içermekteyse de küçük ve orta büyüklükte şirketler bakımından dezavantajlarının da bulunduğu söylenebilir ${ }^{45}$. Buna karşılık şirketin irade özgürlüğünün geniş olması durumunda şirket daha verimli ve daha esnek çalışabilir ${ }^{46}$. Bu esneklik ise, şirkete ihtiyaçları doğrultusunda organizasyon yapısını değiştirme imkânı verir ${ }^{4}$.

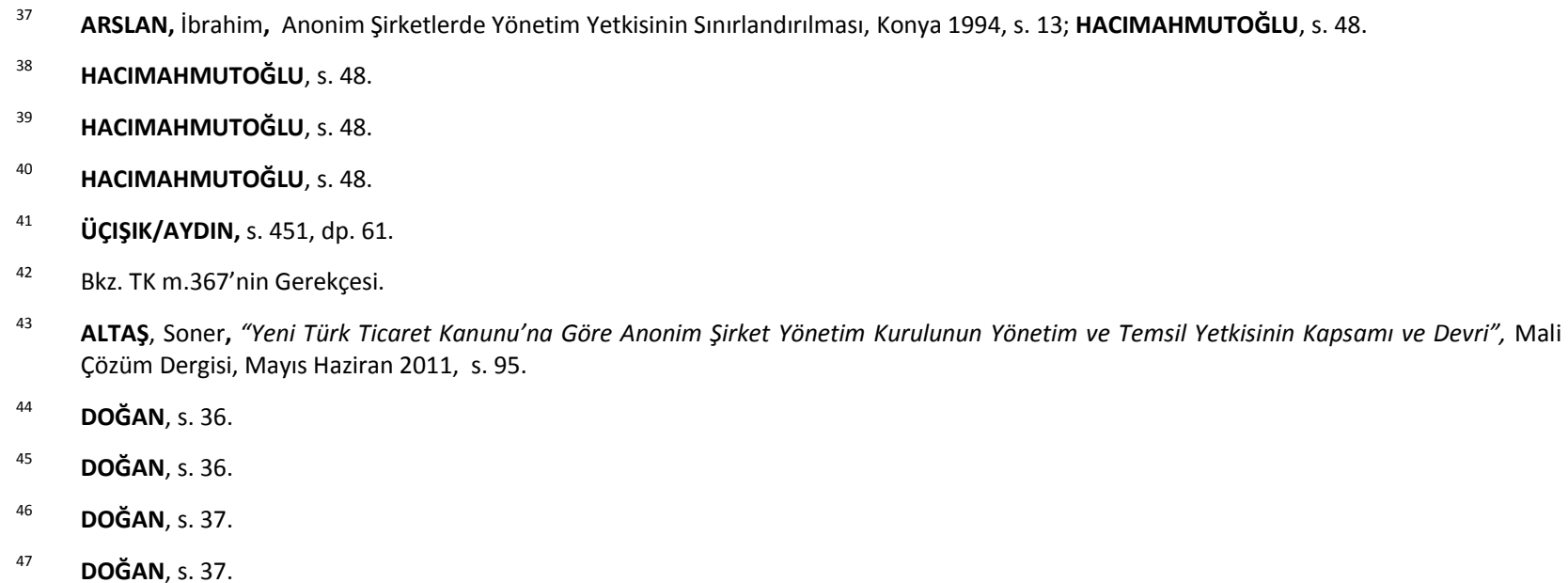


Organizasyon özgürlüğünün kapsamı, şirketin büyüklüğüne ve faaliyet alanına göre değişmektedir. Şirketler, kanunun emredici hükmü sınırları içinde gelişen ekonomik olaylara karşı esnek bir şekilde yönetim yapısını dizayn edebilmektedir ${ }^{48}$. YK, esas sözleşmedeki hükme dayanarak, TK m.367 gereğince bir iç yönerge hazırlayarak yönetim yetkisini kısmen veya tamamen kendi üyelerine veya üçüncü kişilere devredebilecektir. YK, bu iç yönergede yönetimi organize etmek için gerekli görev mevkilerini gösterir, görevleri tanımlar kimin kime bağlı olarak çalışacağını ve bilgi sunmakla yükümlü olduğunu düzenler (m. 367,1).

Organizasyon özgürlüğünün sınıına baktığımızda, ilk olarak esas sözleşmede yetki devrine ilişkin bir hükmün bulunması hali karşımıza çıkmaktadır (m. 367,1). Zira esas sözleşmede bu yönde bir hüküm yoksa yetki devri yapılamaz. íkinci olarak, şirketin monist veya dualist sistem içerisinde yer alması şirket yönetimin organizasyon yapısını doğrudan etkilemekte ve sınırlandırmaktadır. Örneğin, hukuk sistemimizde zorunlu olmayan gözetim kurulunun oluşturulması, Almanya'da zorunludur. Şunu da önemle belirtmek gerekir ki, TK'da gözetim kurulunun oluşturulmasını engelleyecek bir hüküm de bulunmamaktadır ${ }^{49}$. Ancak TK'da anonim şirketin organları, YK ve GK olarak sayılmıştır. TK'da kural olarak, emredici hükümler ilkesi benimsenmiştir ${ }^{50}$. Bu ilke gereğince, kanunda açıkça aksi yönde düzenleme yapılmasına izin verilen durumlar haricinde, şirketlerin esas sözleşme ile kendi hukuk alanlarını düzenlemesi serbestîsi bulunmamaktadır. Ancak TK m.367 düzenlemesi şirketlere önemli ölçüde serbesti tanımaktadır.

Kurumsal yönetim ilkeleri de şirket yönetim organizasyonunu hakkında bağlayıcı olmayan birçok hüküm içermektedir. Şirketler bu hükümlere uyma konusunda serbesttirler. Ancak SPK ilkelerini uygulamayan şirket bu konuda açıklama yapmak zorundadır ${ }^{51}$. SPK ilkelerine göre yönetim kurulu üyelerinin birden fazla olması halinde en az üçte birinin bağımsız üyelerden oluşması gerekmektedir ${ }^{52}$. Hatta Almanya'da yönetici kurul üyelerinin belli çoğunluğunun kadınlardan oluşması da tartışma konusudur ${ }^{53}$. Bu da şirketin yönetim organizasyonu özgürlüğünü sınırlandıran bir etkendir.

\section{YÖNETIMIN DEVRi}

\subsection{Genel Olarak}

TK'da, YK'nın hemen hemen üyelerinin tümünün, yürütme yetkisini haiz olmayan (non-executive) üye konumuna geçebildiği esnek bir rejim benimsenmiştir ${ }^{54}$. Kanun m. 367/1'e göre, YK, esas sözleşmeye konulacak bir hükümle, düzenleyeceği bir iç yönergeye göre, yönetimi, kısmen veya tamamen bir veya birkaç yönetim kurulu üyesine veya üçüncü kişiye devretmeye yetkili kılınabilir. Bu şekilde yetkiyi devreden YK üyeleri, şirketin iş akışına ve olağan faaliyetlerine müdahil olmaksızın yetki ve görevleri devralanları gözetme kurulu gibi çalışacaktır ${ }^{55}$. Çünkü YK yönetim ve temsil yetkisini bizzat kendisi kullanmak zorunda değildir ${ }^{56}$. merkezi/fikir-ureten-fabrikadan/ust-yonetimde-kadin-temsili--avrupa-birligi-ve-turkiyedeki-gelismeler/-03.10.2015. Deutsche Telekom Almanya'da gönüllülük esaslı kadın kotasını uygulayan ilk büyük şirkettir. 2010 yılında uygulamaya başlanan girişimin hedefi 2015 yılına kadar orta ve üst yönetim kademelerindeki kadınların oranını en az \%30'a çıkarmaktır. Kotaya karar verilmesinin en önemli nedeni, alınmış olan diğer tedbirlerin etkili olmamasıdır. Örneğin, 2001 yılında Almanya'nın ileri gelen şirketleri kadın ve erkek çalışanlara eşit fırsatlar verilmesini desteklemek için bir anlaşma imzalamış ancak bu durum kadınların yönetimlerde düşük temsilini değiştirmemiştir. Zorunlu kota uygulayan ülkeler: Norveç, İspanya, Fransa, Hollanda, İtalya ve Belçika'dır. Yönetim kurulunda cinsiyet çeşitliliği konusunda bkz. KARAYEL, Mete/DOĞAN, Mesut, "Yönetim Kurulunda Cinsiyet Çeşitliliği ve Finansal Performans ilişsisi: BisT 100 Şirketlerinde Bir Araştırma", Süleyman Demirel Üniversitesi, IiBF Dergisi, C. 19, S. 2, s. 75 vd.

$54 \quad$ Bkz. m. 367'nin gerekçesi.

55 KIRCA/ŞEHIRALI ÇELIK/ MANAVGAT, s. 592. 
Yönetimin usulüne uygun devriyle kastedilen, YK'nın devredilmez ve vazgeçilmez yetkileri hariç olmak üzere, şirketin işletme konusunun gerçekleştirilmesi için gerekli olan iş ve işlemler hakkında karar alma yetkisini, 367,1 'de öngörülen usule uygun biçimde tamamen veya kısmen bir veya birkaç YK üyesine veya üçüncü kişiye devretmesidir" ${ }^{57}$. TK m. 367 hükmündeki yönetimin devri, iBK m. 716b hükmünde "Übertragung der Geschaftsführung" başlıklı maddede düzenlenmiştir. "Geschaftsführung" kelimesi işgören, iş yapan kimse, kısaca yönetici olarak tanımlanmaktadır ${ }^{58}$.

Devrin sınıını m. 375'te sayılan YK'nın devredilmez görev ve yetkileri oluşturacaktır ${ }^{59}$. Bu sınıra uyulmak şartıyla görev ve yetkiyi devralanlar m. 374,1 bağlamında kendisine bırakılan alanda yönetim, kanun ve esas sözleşme uyarınca genel kurulun yetkisinde bırakılmış bulunanlar dışında, şirketin işletme konusunun gerçekleştirilmesi için gerekli olan her çeşit iş ve işlemler hakkında karar almaya yetkilidir.

Kanun koyucu, yönetimin devri ile işin niteliği gereği organa özgü yetkilerin, yani organsal işlevin devrini kastetmiştir $^{60}$. Organa özgü yetki, şirketin iradesinin oluşumunda belirli etkisi bulunan yetkidir ${ }^{61}$. Bu yetki kural olarak şirketin üst yöneticileri tarafından kullanılır. Bu yüzden bu yetkileri devralan kişiler, organ ${ }^{62}$ sıfatına sahip olur $^{63}$ ve YK üyeleri ile aynı özen ve bağlılık yükümlerine ve sorumluluk rejimlerine tabi tutulurlar ${ }^{64}$.

Yönetimin devrine ilişkin hükümler, son derece önemli hükümlerdir. Bu yüzden Kanun tarafından yönetimin devrinin çerçevesi çizilmiş, usul ve esasları belirlenmeye çalışılmışır.

$\mathrm{YK}$, işlerin gidişini izlemek, kendisine sunulacak konularda rapor hazırlamak, kararlarını uygulatmak veya iç denetim amacıyla içlerinde yönetim kurulu üyelerinin de bulunabileceği komiteler ve komisyonlar kurabilir ( $\mathrm{m}$. 366,2 ). Yönetimin devri ile komite ve komisyonların kurulması birbirinden farklıdır. Komite ve komisyonların kurulmasında yönetimin devrinde aranan şartlar aranmaz. Ancak bazı şirketler için Kanundan veya esas sözleşmelerinden kaynaklı, kurulması zorunlu olan komitelerin/komisyonların kurulması ve bu kişilere şirketin iç işlerinde (yönetimde) görev ve yetki verilmesi halinde kanunda belirtilen şekilde iç yönerge hazırlanması veya hazırlanmış bir iç yönergede bu komite/komisyonların da belirtilmesi gerekir.

Yapılan işlemin imza yetkisi devri mi, yönetimin devri mi yoksa komite ve komisyon oluşturulması mı olduğunun tespitini $\mathrm{m}$. 367,1'deki şartların olup olmadığına göre belirleyeceğiz. Bu ayrımın yapılması anonim şirketlerde sorumluluk açısından önemlidir. Zira, 366,2'nin uygulandığı durumlarda sorumlulukla ${ }^{65}$ ilgili 553,2 devreye girmez $^{66}$.

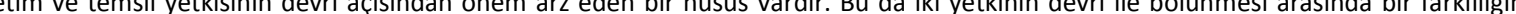
olduğuna işaret etmek gerekir. Yeni TK gereği, yönetim kurulu, her yıl üyeleri arasından bir başkan ve bulunmadığı zamanlarda ona vekâlet etmek üzere en az bir başkan vekili seçecektir (m.366,1). Ancak, Kanun, bu görevlendirmenin yıllık olarak yapılmasını öngörmektedir. Dolayısıyla, yönetim kurulu üyeleri iki veya üç yıllık bir süre için seçilmiş dahi olsalar, anılan seçiminin her yıl yapılması gerekir. Yoksa yönetim kurulu, üyelerinin görev süresine paralel şekilde, iki ya da üç yıllık bir süre için başkan ve başkanvekili seçimi yapamaz. Bkz. ALTAŞ, s. 94. Yetkili organın kendisine ait devredilemez ve vazgeçilemez görev ve yetkilerinin dışında kalan görev ve yetkileri kısmen veya tamamen başkasına bırakmasıyla devreden açısından sorumsuzlaşma, devralan açısından müstakil hamil kavramı ortaya çıkar. Bkz. TEKiNALP, Sermaye Ortaklıkları, s.219.

64 KIRCA/ŞEHIRALi ÇELIK/ MANAVGAT, s. 593.

65 YK üyelerinin sorumluluğu kural olarak kusur sorumluluğudur. TK m. 553,1 ve 2'de açıkça kusura atıf yapılmıştır. Ancak 371,7'de kusurdan bahsedilmemiştir. Ayrıntılı bilgi için bkz. CEYLAN, s. 34.

KIRCA/ŞEHIRALI ÇELIK/ MANAVGAT, S. 593. 


\subsubsection{Yönetimin Devredileceği Kişiler}

Şirket yönetimine ilişkin yetkiler kısmen veya tamamen bir ve birkaç YK üyesine veya üçüncü kişiye devredilebilir (m. 367,1). Yönetimin devredileceği kişi YK üyesi ise bu durumda bir sorun ortaya çıkmaktadır. Eğer devir yapılan kişi yönetimin başı ise YK'nın üst gözetim görevini yerine getirmesi güçleşmektedir ${ }^{67}$. Maddede geçen üçüncü kişi, YK üyesi olmayan kişilerdir. Bu kişinin şirket çalışanı olmasında herhangi bir sakınca yoktur. Ayrıca yönetimin profesyonel bir şirkete devri halinde söz konusu üçüncü kişinin tüzel kişi olması da mümkündür ${ }^{68}$. Çünkü yeni TK'nın anonim şirketin yönetimine ve temsiline ilişkin düzenlemelerinin profesyonel yönetim ve şeffaflık ${ }^{69}$ ilkeleri çerçevesinde şekillendirildiği belirtilmektedir ${ }^{70}$.

Devrin bir kişiye veya birden fazla kişiye yapılması, işletmenin çapı ve büyüklüğü yanında YK'nın tercihine de bağııdır. Birden fazla kişiye aynı görev ve yetki devredilebileceği gibi, bu kişilere ayrı ayrı görev ve yetkiler de devredilebilir. Bir görevin birden fazla kişiye devredilmesi durumunda kuruldan bahsedilir. YK, bu kurul ile irtibatın sağlanması için kurula bir başkan da atayabilir. Önemle belirtmek gerekir ki, kurulun çalışma usulü, görev ve yetkileri iç yönergeyle belirlenmelidir $(367,1)$. Gerekirse YK'nın çalışma usulüne ilişkin kurallar, yapısıyla bağdaştığı ölçüde devir sonucu oluşturulan kurul için de uygulanabilir ${ }^{71}$.

Yönetimin devredildiği üçüncü kişiler ile şirket arasında çoğu zaman bir hizmet akdi olduğu kabul edilmektedir $^{72}$. Bunun yanında Kanunda da bu kişiler için bir takım hak ve yükümlülükler öngörülmüştür.

6552 s. Kanun m. 131 ile TK’nın 371. maddesine 7. fıkra eklenmiştir. Bu yeni fıkra, esas itibariyle temsile yetkili olmayan YK üyesinin ticari vekil olarak atanmasına ve bu şekilde atanan ticari vekil ile onun yetkisine getirilen her tür sınırlamanın tescil ve ilanına ilişkindir. Fıkranın ilk cümlesi uyarınca YK, temsile yetkili olmayan YK üyelerini ve şirkete hizmet akdi ile bağlı olanları sınırlı yetkiye sahip ticari vekil veya diğer tacir yardımcıları olarak atayabilir. Ticari vekil BK'da düzenlenmiştir (m.551 vd.). Ancak bu maddede geçen ticari vekil, yetkilerinin kapsamı sınırlandıran ticari vekildir. Sınırlı yetkiye sahip ibaresinden yola çıkarak, BK'da düzenlenen ticari vekilden farklı bir temsilcinin var olduğu söylenebilir. Sınırlı yetkiye sahip ticari vekil ile özel yetkili ticari vekil kastedilmiş olabilir ${ }^{73}$. Ancak BK'da sınırlı yetkili ticari vekil terimi yer almamaktadır. Sınırlı yetkiye sahip ticari vekil ile kastedilen genel veya özel yetkili olması fark etmeksizin kanunda belirtilen temsil yetkisine sınırlama getirilen ticari vekil olmalıdır ${ }^{74}$. BK'daki ticari vekil atama açısından herhangi bir tescil ve ilan işlemine tabi tutulmazken, bu fıkra uyarınca atanan sınırlı yetkiye sahip ticari vekil öncelikle iç yönerge ile atanmalı ve tescil ve ilan edilmelidir. Şunu da önemle belirtmek gerekir ki, m. 367 uyarınca hazırlanan iç yönerge şirketin iç işleri ile ilgili olduğu için tescil edilmeyecektir. Ancak pay sahiplerini ve korunmaya değer menfaatleri olan alacaklıları yazılı olarak bilgilendirmek gerekir ${ }^{75}$.

Sınırlı yetkili ticari vekilin ve diğer tacir yardımcılarının görev ve yetkileri iç yönerge ile belirlenecektir. Daha sonra bu iç yönergeye atıf yapılarak sınırlı yetkili ticari vekil ve diğer tacir yardımcıları atanacaktır. Maddede temsile yetkili olmayan YK üyeleri ve şirkete hizmet akdi ilişkisi olanların bu fıkra anlamındaki görev ve bir şekilde uygulanması açısından büyük bir önem taşımaktadır. Zira şeffafık, şirketin mali yapısının saydamlığı yanında kurumsal yapının da netliğini de gerektirmektedir. Ayrıca organların aldıkları kararlar konusunda hesap verebilir durumda olma yükümlülügü ve ilgililere karşı sorumlu olmaları, bu organların hukuki konumlarının netleştirilmesini gerekli kılmaktadır". Bkz. KARASU, Rauf, "6102 Sayılı Türk Ticaret Kanunu Ile Anonim Şirketlerde Kurumsal Yönetim Ile Ilgili Getirilen Yenilikler", iÜHFD, C. 4, S. 2, 2013, s. 39.

KIRCA/ŞEHIRALI ÇELIK/ MANAVGAT, s. 596.

KIRCA/ŞEHIRALI ÇELIK/ MANAVGAT, s. 596.

ALTAŞ, s. 91.

KIRCA/ŞEHIRALI ÇELIK/ MANAVGAT, s. 597.

KIRCA/ŞEHIRALI ÇELIK/ MANAVGAT, s. 597.

Özel yetkili ticari vekil için bkz. ARKAN, Sabih, Ticari İşletme Hukuku, 19. Baskı, Ankara 2014, s. 182.

KIRCA, İsmail, "TTK m. 371.7 Hakkında Bir inceleme: AB'ye Üyelik Yolunda Geri Adım”, BATiDER, C. XXX, S. 3, 2014, (TTK m. 371.7 Hakkında) s. 26.

KIRCA/ ŞEHIRALI ÇELIK/ MANAVGAT, s. 607. 
yetkilerinin iç yönergede belirtilmesi aranmıştır. İ̧ yönerge ile bu kişilerin görevleri konu, miktar açısından sınırlandırılabilecektir. Hatta birlikte temsil ve şube işleri ile sınırlama da mümkündür. Bu sınırlamalar aynı anda hepsi birden yapılabileceği gibi sadece bir veya birkaçı da yapılabilir.

iç yönerge ile sadece sınırlı yetkiye sahip ticari vekil ve diğer tacir yardımcılarının görev ve yetkileri belirlenmeyecektir. İç yönerge, YK'nın görev dağııımını, imza yetkililerini murahhas üyeyi, murahhas müdürü, ticari mümessili, ticari vekili düzenleyecektir. İç yönergede devrin sorumluluğa etkisi açısından görev dağııımının ve yetki paylaşımının yapılması TK m.553 hükmünün uygulanması açısından önemlidir ${ }^{76}$.

Diğer tacir yardımcılarından kastedilen müdür, şef, amir gibi şirketin olağan işlerini yapan kişilerdir. Bu kişilerinde YK üyeleri arasından veya şirkete hizmet akdi ile bağlı olan kişiler arasından seçilmesi halinde iç yönergenin tescil ve ilanı gerekecektir. Yönetim kurulu üyelerinin temsile yetkili olmayanlar arasından seçilmesi gerekir. Bunun için, öncelikle bu üyenin TK m.370,2 uyarınca temsil yetkisinin elinden alındığına yönelik bir yönetim kurulu kararı olmalıdır ${ }^{77}$. Sicil müdürü böyle bir karar olmadan 7.fıkraya göre yapılan bir atamanın tescili talebini reddetmelidir. Temsile yetkili olmayan yönetim kurulu üyesinin ticari vekil olarak atanması için bir engel bulunmamalıdır ${ }^{78}$. Kendisine ticari vekil veya sınırlı yetkiye sahip diğer tacir yardımcısı görev ve yetkisi verilen kişilerin de yönetim kurulu toplantısında müzakerelere katılması ve oy kullanması hususunda bir engel yoktur ${ }^{79}$.

TK m.371,7 sorumluluk rejimi açısından m.553,2'ye bir istisna teşkil etmektedir. 553,2 uyarınca yönetim kurulu uhdesinde bulunan bir görev veya yetkiyi usulüne uygun biçimde devrederse bu görev ve yetkileri devralan kişilerin seçiminde makul derecede özen göstermek kaydıyla, bu kişilerin fiil ve kararlarından sorumlu olmaz. Ancak m.371,7'de sınırlı yetkiye sahip ticari vekil veya diğer tacir yardımcıları olarak atanan temsile yetkili olmayan yönetim kurulu üyeleri ve şirkete hizmet akdi ile bağılı olanların şirkete ve üçüncü kişilere verecekleri her türlü zarardan dolayı YK müteselsilen sorumludur. Önemle belirtmek gerekir ki, 553,2 organa özgü yetkilerin devrinde uygulanmakta, çalışanların ve yardımcı kişilerin tayininde uygulanmamaktadır ${ }^{80}$. Eğer ticari vekilleri organ olarak kabul etmezsek 7.fıkranın son cümlesi bu açıdan yeni bir şey getirmiş sayılmayacaktır ${ }^{81}$. Ancak ticari vekilin organ olduğu kabul edilirse aksi mümkündür.

Limited şirketlerde bu hükmün uygulanması 629. maddeye eklenen 3.fıkra ile mümkün hale gelmiştir. Müdür veya müdürler kurulu tarafından şirketin yönetiminin devrini düzenleyen ve bunun iç yönerge hazırlanmasını arayan $\mathrm{m} .367$ 'nin muadili limited şirketlerle ilgili hükümler arasında yer almamaktadır. Temsil yetkisinin devrini düzenleyen m.370,2'ye benzer bir hükümde limited şirketler için de söz konusu değildir. Ancak m.577,1, 623,1, 625,1 ve 629,1 hükümlerinden hareketle yönetim ve temsilin müdürler arasında veya üçüncü kişiye devri mümkün olmalıdır. Temsile yetkili olmayan müdür kavramı 629,3'te yer almamaktadır. Limited şirketlerde ticari vekil, aksi şirket sözleşmesinde düzenlenmediği takdirde genel kurul tarafından atanacaktır. Hal böyle olunca 629,3 'te açıkça müdürler tarafından sınırlı yetkiye sahip ticari vekil veya diğer tacir yardımcılarının atanmasından söz etmesinden ötürü her halde şirket sözleşmesi ile ticari vekil atamasının müdürlere bırakıldığı durum kastedilmiştir. Bu hükmün limited şirketlerde uygulanabilmesi için: şirket sözleşmesinde ticari vekilin müdürler tarafından konulacağına yönelik bir hüküm bulunmalı, yine şirket sözleşmesinde iç yönerge hazırlanacağına dair bir madde yer almalıdır. Limited şirketin müdürlerinin birden fazla olması halinde hangilerinin icracı olmadığı da belirtilmelidir.

\footnotetext{
KIRCA, TTK m. 371.7 Hakkında, s. 29.

KIRCA, TTK m. 371.7 Hakkında, s. 33.

KIRCA, TTK m. 371.7 Hakkında, s. 33.

KIRCA, TTK m. 371.7 Hakkında, s. 33.

KIRCA, TTK m. 371.7 Hakkında, s. 35.

KIRCA, TTK m. 371.7 Hakkında, s. 35.
} 
7. fıkra ile gelen düzenleme Soma maden faciası ve asansör kazası sonucu iş kazalarında hayatını kaybeden iş̧̧ileri hiç görmemiş şirket sahiplerinin sorumluluğuna çare olsun diye getirilmiştir ${ }^{82}$. Ancak bu düzenleme, BK m. 551 vd. ticari vekil ve diğer tacir yardımcılarına yönelik hükümler getirdi. Fıkranın sonuna eklenen, "Bu kişilerin, şirkete ve üçüncü kişilere verecekleri her tür zarardan dolayı yönetim kurulu müteselsilen sorumludur" diyerek hem cezai yönden hem de hukuki yönden YK'yı müteselsil sorumlu tutmuştur. Bu hüküm, kanuna uygun yetki devri ile sorumluluğun da devredilmesi kuralına istisnadır. Burada kanun koyucu, YK'nın, riskli ve ağır sorumluluğuna sebep olacak işleri bir kimseye devredip sorumluluktan bertaraf olmasını engellemiştir.

Son olarak birlikte imza yetkisine sahip kişilerin sadece belirli bir işlem için üçüncü bir kişiye yetkilendirme yapmaları bu kapsamda değerlendirilmemelidir ${ }^{83}$.

\subsubsection{Devrin Kapsamı}

YK, esas sözleşmeye konulacak bir hükümle, düzenleyeceği bir iç yönergeye göre, yönetimi, kısmen veya tamamen devretmeye yetkili kılınabilir $(367,1)$. Yönetim ister tamamen ister kısmen devredilsin, YK'nın, başta m. 375'te sayılan, devredilmez görev ve yetkileri devre konu olmaz. Devredilmez görev ve yetkilerin devre konu olması halinde YK kararı batıl olur $(391,1, \mathrm{~d})$.

Yetkinin tamamen devrinde şirketin faaliyet konusunu gerçekleştirebilmesi için gerekli olan her tür iş ve işlemler hakkında karar alma yetkisi, bir ayrım yapılmadan devredilmektedir. Bu devir bir kişiye yapılabileceği gibi ayrı ayrı veya birlikte hareket etmek üzere birkaç kişiye de yapılabilir.

Yetkinin kısmi devrinde ise faaliyetler, örneğin, personel ve insan kaynakları, muhasebe, mali işler, pazarlama, satış vs. gibi kısımlara ayrılmaktadır. Yönetimin yapması gereken bu görevlerden bir veya bir kaçı aynı ve farklı kişilere veya kurullara devredilmektedir. Özetle, yönetimin kısmen devrinde YK, devredilmez ve vazgeçilmez görev ve yetkilerinin yanında şirketin işletme konusunun gerçeklemesi için gerekli olan iş ve işlemlerin de bir kısmını uhdesinde tutmaktadır ${ }^{84}$.

YK yetkiyi devrederken önemli gördüğü bazı hususlarda karar alınmasını kendi onayına tabi tutabilir mi? Bunun kabul görmesi halinde sorumluluk hükümlerinin uygulanmasında herhangi bir değişiklik olur mu? YK, devrettiği yetkiler için karar alınmasını kendi onayına tabi tutabilir. Bu halde YK'nın onayıyla alınan kararlarda sorumlu YK'dır. Yine bu durumda YK, gözetim ve özen yükümünü gerekçe gösterilerek sorumluluktan kurtulamaz.

Yönetimin devrinin kapsamında genel kurulun esas sözleşmeye koyacağı bir hükümle daralma ve genişleme olacağı şüphesizdir. Çünkü yetki devrini düzenleyen m. 367'e baktığımızda "esas sözleşmeye konulacak bir hükümle" bu devrin yapılması kanuni zorunluluktur.

4857 iş̧ Kanunu 2. maddesi; bir iş sözleşmesine dayalı çalışan gerçek kişiye işçi, işçi çalıştıran gerçek veya tüzel kişiye yahut tüzel kişiliği olmayan kurum ve kuruluşları işveren olarak nitelemiştir. Aynı şekilde 5510 sayılı Sosyal Sigortalar ve Genel Sağlık Sigortası Kanunu 12. maddesi de 4. maddenin 1. fıkrasının (a) ve (c) bentlerine göre, sigortalı sayılan kişileri çalıştıran gerçek veya tüzel kişiler ile tüzel kişiliği olmayan kurum ve kuruluşlar işveren olarak kabul edilmişlerdir. İş akdinin tarafı olan AŞ iş görme ediminin alacaklısı olarak işin görünmesini isteme hakkının sahibidir. Buna karşılık yönetim hakkı ve emir ve talimat verme yetkisi ise zorunlu olarak YK tarafından kullanılır. Tüzel kişi işverenlerde, Tüzel kişi soyut, tüzel kişinin organı ise somut işveren sıfatına haizdir. Esasen tüzel kişinin organı tüzel kişiden ayrı bir varlık olmayıp, onun bir parçasıdır. İradesi, tüzel kişinin iradesi sayılır ve tüzel kişiye organik bir bağ ile bağlıdır. Başka bir anlatımla, organlar tüzel kişinin temsilcisi olmayıp, tüzel kişinin kendisidir ve bunlar organ sıfatıyla işverendirler. TTK 367. maddesi uyarınca anonim şirketin yönetim ve temsil yetkisi kendisine bırakılan kişi organ olarak somut işveren niteliğini taşır. Ticaret şirketlerinde işveren niteliği soyut ve somut olarak iki biçimde ortaya çıkmaktadır. Salt tüzel kişiliği bulunan ticaret şirketi soyut işveren ve bu şirketin organları olan ortaklar, pay sahibi olan müdürler, yönetim kurulları somut işveren olarak belirlenir. Şirket idare ve temsil yetkisinin dışarıdan seçilmiş bulunan kişi veya müdürlere bırakılması durumunda bu kişiler işveren vekili sıfatını kazanırlar. Ticaret şirketlerinin işveren olması bu sıfatından doğan bazı yetkilere sahip bulunduğu gibi birçok sorumlulukların da muhatabı kılmaktadır. İşverenin iş mevzuatından doğan yükümlülüklerini ve sözleşmelerden doğan borçlarını yerine getirmemesi durumunda hakkında hukuki ve cezai yaptırımların uygulanması gerekir. Ayrıntılı bilgi için bkz. ARASLI, Utkan, "Ticaret Şirket Organlarının Iş Kazasından Kaynaklanan Hukuksal ve Cezai Sorumluluğu", Çimento İşveren Dergisi, Temmuz 2010, s. 29-30. Anonim şirketlerde YK'nın iş ve sosyal güvenlik mevzuatı karşısında hukuki durumu için ayrıca bkz. GÜNDOĞDU, Gökmen/KAPLAN, Hasan, "Anonim Ortaklık ile Isş̧i Arasındaki ilişkide Yönetim Kurulu Üyesinin Hukuki Durumu”, iüHFM, C.LXV, S. 2, 2007, s. 253.

83 Şirketi birlikte temsile yetkili kişiler şirketin organı olmaları sebebiyle, üçüncü kişiye verilen böyle bir yetki alt temsil yetkisi olarak nitelendirilmemelidir. Bkz. KIRCA, Birlikte Temsil, s. 461. 


\subsubsection{Devrin Şartları}

Kanun m. 367,1'e göre, usulüne uygun bir yetki devri için şu şartların bir arada bulunması gerekir $\left.{ }^{85}: 1\right)$ Esas sözleşmede devre izin veren bir hükmün olması gerekir. 2) YK tarafından 367,1'de belirtilen asgari içeriğe sahip usulüne uygun bir iç yönerge hazırlanmalı ve onaylanmalıdır. 3) YK'ca yetki devri kararı, bu iç yönergeye uygun yapılmalıdır. 4) Devredilen yetki, YK'nın 375. maddesi kapsamındaki devredilmez ve vazgeçilmez yetkilerinden olmamalıdır.

\section{ESAS SÖZLEŞMEDE HÜKÜM BULUNMASI}

Yetkinin devri için şirket esas sözleşmesinde bu yönde bir hüküm olmalıdır ${ }^{86}$. Bu hükmün şirketin kuruluşunda konulması ile daha sonraki süreçte genel kurul tarafından yapılan bir esas sözleşme değişikliğiyle konulmasında herhangi bir fark yoktur ${ }^{87}$.

Esas sözleşme hükmü bulunmaksızın genel kurulun esas sözleşmenin değiştirilmesine yönelik olmayan bir yetki kararı, 367,1'de öngörülen yetki şartını sağlamaz. Esas sözleşmenin yetki devrine ilişkin kararı açık ve anlaşılır olması gerekir. Çünkü yetki devri usulüne uygun yapılmadığı sürece, şirketin bütün iş ve işlemlerinden YK üyeleri sorumludur.

Yönetimin devri kural olarak temsil yetkisinin devrini içermez ${ }^{88}$. Temsil yetkisi de devredilmek istenirse bu hususun esas sözleşmede yer alması gerekir ${ }^{89}$.

Esas sözleşmeye hiçbir yetki hükmü konulmayabilir. O halde çoğun içinde az da vardır ilkesi gereği esas sözleşmedeki yetki hükmü yönetimin devrine kişi veya konu ${ }^{90}$ bakımından sınırlama getirebilir $^{91}$.

Esas sözleşmedeki yetki hükmü, yönetimin bir YK üyesine devredileceği yönünde olabileceği gibi, yetkinin üçüncü kişilere devrini de içerebilir. Esas sözleşme ile yetkilerin bir kısmının YK'da kalacağı bir kısmının devredileceği düzenlenebilir. Yönetimin devredileceği kişinin esas sözleşmeyle belirlenmesi, yönetimin devri mecburiyetinin getirilmesi ve yönetimin devrinin genel kurul kararına bırakılması mümkün değildir ${ }^{92}$. Çünkü yönetim teşkilatını belirleme yetkisi m. 375,1-b gereği YK'nın devredilmez ve vazgeçilmez görev ve yetkilerindedir. Müdürlerin ve aynı işleve sahip kişiler ile imza yetkisini haiz bulunanların atanmaları ve görevden alınmaları da m. 375,1-d gereği YK'nın devredilmez ve vazgeçilmez görev ve yetkilerindedir. İç yönergenin kabul edilmesi ve yetki devri genel kurul kararına bırakılamaz ${ }^{93}$. İç yönerge veya yetki devrini konu alan bir genel kurul kararı istişari nitelik taşır ${ }^{94}$.

\section{1. İç Yönerge Hazırlanması}

YK, yönetim yetkisini kısmen veya tamamen devredebilmesi için 367,1 hükmü uyarınca esas sözleşmedeki yetkilendirme temeline dayalı olarak bir iç yönerge hazırlar. Yetki devrinin yapılabilmesi için iç yönergenin hazırlanması şarttır. YK şirketi bizzat yönetiyorsa iç yönergeye ihtiyaç yoktur diyemeyiz. Çünkü iç yönerge;

KIRCA, İsmail, "6102 Sayılı Türk Ticaret Kanununda Anonim Şirket Yönetim Kurulu-Başlıca Değişiklikler", EÜHFD, C. XVI, S. 3-4, Aralık 2012, (Başlıca Değişiklikler), s. 136.

Oysa mehaz kanunda esas sözleşmede hüküm bulunmasa dahi iç yönetmelikte temsil yetkisinin devri mümkündür. Bu yüzden m. 370 hükmü m.367 ile birlikte değerlendirilmelidir. Bkz. AKDAĞ GÜNEY, YK, s.79.

KIRCA/ŞEHIRALI ÇELIK/ MANAVGAT, s. 600.

TK m. 367'nin Gerekçesi. Gerekçede temsil yetkisinin 370. Maddeye göre ayrıca veya aynı işlemle açıkça belirtilmek suretiyle devri gerektiği belirtilmiştir.

CEYLAN, S. 28.

KIRCA/ŞEHIRALI ÇELIK/ MANAVGAT, s. 601.

TK m. 371,7 ile gelen düzenleme temsil yetkisinin yer ve birlikte imza dışında sınırlamaya imkân vermektedir. CEYLAN, s. 35 .

KIRCA/ŞEHIRALI ÇELIK/ MANAVGAT, s. 602.

TEKINAP, Sermaye Ortaklıkları, N. 12-56.

KIRCA/ŞEHIRALI ÇELIK/ MANAVGAT, s. 603. 
yönetim kurulunun oluşması, müzakerelerin akışı, kararların alınması ve özellikle kurumsal yönetim ilkeleri gereğince YK kararlarının hazırlanması ve icrasıyla hangi üyenin yetkili olduğunu veya icra yetkisi olmayan YK üyelerinin hangisinin denetimden sorumlu olduğu gibi hususları da içerir ${ }^{95}$.

\subsection{1. İç Yönerge Kavramı}

iç Yönerge, şirketin yönetimini düzenleyen; bunun için gerekli olan görevleri tanımlayan, özellikle kimin kime bağlı ve bilgi sunmakla yükümlü olduğunu belirleyen ve YK'nın şirket yönetimini, kısmen veya tamamen bir veya birkaç yönetim kurulu üyesine veya üçüncü kişiye devretmesine ilişkin usul ve esasları düzenleyen YK tarafından düzenlenen bir metindir $(367,1)$. İç yönerge ayrı bir doküman olarak hazırlanabileceği gibi, YK'nın bu konuda yazııı kararı veya protokolü de olabilir ${ }^{96}$. Iç yönergenin değiştirilmesi de YK tarafından yapılır. İç yönergenin değiştirilmesi, iç yönergenin eskimiş ve aşılmış olduğu ve artık gerçeği yansıtmadığı durumlarda problemlerin önüne geçilmesi için gereklidir ${ }^{97}$.

Anonim şirketler hukukuna konu olan iç yönerge şirket içi işleyişe ilişkin bir metindir. iç yönerge, şirket organlarının aldığı bir karar ile kendi görev alanına giren konulara ilişkin olarak hazırlanan yazılı ${ }^{98}$ düzenlemelerdir. İç yönergeler, kanun veya esas sözleşmede düzenlenmesi zorunlu olmayan, aksine esas sözleşmenin içeriğini tamamlayan ve somutlaştıran konularda düzenlemeler içerebilir ${ }^{99}$. Şirketler hukuka anlamında bir yönergeden bahsedebilmek için iki şekli şartın birlikte gerçekleşmesi gerekmektedir: 1. iç yönerge yazılı olarak hazırlanmalı ve 2 . yetkili organın geçerli bir kararına dayanmalıdır ${ }^{100}$.

İsviçre hukuku ve TK'ya göre, iç yönergesinin yazılı olarak hazırlanması gerekmektedir. Bu zorunluluk TK m. 390/V gereğince, yönetim kurulu kararlarının yazılı olması zorunluluğundan kaynaklanmaktadır. Yönergeler şirketin birçok çalışanına hitap ettiğinden ve uzun süre uygulanması mümkün olduğundan yazılı olarak hazırlanmasında pratik açıdan fayda vardır ${ }^{101}$. İ̧ yönergelerin yazııı olması yeterli olup, herhangi bir formda hazırlanması zorunluluğu bulunmamaktadır. Yönergeler, yönetim kurulu karar tutanağına yazılabileceği gibi, bağımsız bir metin olarak da hazırlanabilir. Yazılı olmanın gereği olarak yönergeler, ne şekilde kabul edilmiş iseler aynı yöntemle değiştirilebilirler.

\subsection{2. İç Yönergenin Hukuki Niteliği}

iç yönerge; borç doğurmayan ve görev sahiplerine konumları konusunda garanti vermeyen, pay sahiplerine ve alacaklılara bir hak sağlamayan, anonim şirkette yönetimin resmini veren, YK ile yönetim arasındaki sınırı çizen ve yönetimde görev ilişkilerini gösteren bir organizasyon metnidir ${ }^{102}$. Yönetime dair iç yönerge yanlışılıla tescil ve ilan edilse bile üçüncü kişilere karşı hüküm ifade etmeyeceği gibi, üçüncü kişinin müspet vukufu da hiçbir hukuki sonuç doğurmaz ${ }^{103}$. Çünkü iç yönerge işletmenin yönetimine ilişkin olup, üçüncü kişiye hak sağlayacak bir hukuki tasarruf değildir ${ }^{104}$. Ancak sorumluluk yönünden hem şirkette görev sahibi olanlar hem de üçüncü kişiler bakımından delil veya yazııı delil başlangıcı niteliği taşır ${ }^{105}$. Şirket yönetimini düzenleyen m. $367^{\prime}$ de 
öngörülen şartları taşıyan belgenin iç yönerge olarak adlandırılması şart değildir ${ }^{106}$. Ancak temsil yetkisinin devrini düzenleyen iç yönerge üçüncü kişilerin iyiniyetini ortadan kaldırır. Çünkü burada tescilin olumlu etkisi söz konusudur ${ }^{107}$.

Kural olarak yetki devri sorumluluğun devrini de kapsar ${ }^{108}$. Yetki devri halinde YK'nın gözetim ve özen borcunun devam ettiği kabul edilir. Bu açıdan bakıldığında iç yönerge bir gözetim belgesi, gözetim yasasıdır ${ }^{109}$.

TK m. 371'de 10.9.2014'te 6552 s. Kanun m. 131 ile yapılan değişiklikle YK'nın temsile yetkili olmayan yönetim kurulu üyelerini veya şirkete hizmet akdi ile bağlı olanları sınırlı yetkiye sahip ticari vekil veya diğer tacir yardımcıları olarak atayabileceği düzenlenmiştir. Bu şekilde atanacak olanların görev ve yetkilerinin, 367. maddeye göre hazırlanacak iç yönergede açıkça belirlenmesi ve bu iç yönergenin tescil ve ilanı zorunluluğuna dikkat çekilmiştir. Hükme göre, iç yönerge ile ticari vekil ve diğer tacir yardımcıları atanamayacak, atama YK tarafından alınan bir kararla iç yönergeye atıf yapılarak belirlenecektir. Bu maddeye göre yetkilendirilen ticari vekil veya diğer tacir yardımcıları da ticaret siciline tescil ve ilan edilecektir. Tescil edilen hususlar üçüncü kişilerin iyiniyetini kaldıracaktır. İç yönergenin tescil ve ilan edildiği durumda, şirketin, pay sahiplerinin ve üçüncü kişilerin zararları dolayısıyla yöneticilere açacakları sorumluluk davasında sorumluyu belirlemeyi kolaylaştıracaktır ${ }^{110}$.

İç yönergelerin geçerli olabilmesi için yetkili organ tarafından usulüne uygun olarak alınan kararla kabul edilmiş olması gerekmektedir. Yetkili organın nasıl karar alacağı ise kanun, esas sözleşme veya iç yönerge hükümlerine göre belirlenir. Kural olarak her organ kendisi ve alt birimleri için düzenleme yapma yetkisine sahiptir. Bu yetki içinde bir yükümlülüğü de barınmaktadır. Bu sebeple şirketin her bir organı -genel kurul, yönetim kurulu, murahhaslar, komite ve komisyonlar- yetki ve görevlerine ilişkin olarak gerektiği durumlarda, kendisi, kendi bünyesindeki yapılar veya kanunun verdiği yetkiye dayanarak başka bir organ için yönerge hazırlayabilir veya çıkarabilir. Örneğin TK m. 419 hükmü gereğince genel kurul yönergesini yönetim kurulu hazırlar ve genel kurul onaylar. Buna karşılık komite ve komisyonların yönergesini yönetim kurulu hazırlar ve kabul eder. Eğer şirket içerisinde birden fazla yönerge varsa, üst organın yönergesi alt organın/birimin yönergesine nazaran öncelikli uygulanır.

İç yönergeler ikincil/yan düzenlemeler olduğundan kanunların çizdiği sınırlar içerisinde hazırlanmak zorundadır. Esas itibariyle yönergeler kanunlarca organlara tanınan yetkiler çerçevesinde hazırlanabileceğinden kanunlara aykırı olması düşünülemez. Ayrıca kanunlara göre mutlaka esas sözleşmede düzenlenmesi zorunlu kılınan hususlara ilişkin olarak da iç yönerge çıkarılamaz. Kanun, bir hususta düzenleme yapmamışsa veya esas sözleşmeyle veya iç yönergeyle düzenleme yapılabileceği konusunda yetki vermişse, bu durumda o hususa ilişkin yönerge hazırlanabilir veya hazırlanan yönergede o hususa yer verilebilir.

İ̧̧ yönerge ile esas sözleşme arasındaki ilişki aynen tüzük ile kanun arasındaki ilişki gibidir. Esas sözleşme iç yönergeye göre daha üst bir düzenleme olduğundan, ikincil düzenleme konumunda olan iç yönergenin esas sözleşme hükümlerine aykırı olmaması gerekir ${ }^{111}$. Bunun yanı sıra eğer kanun, esas sözleşmede ve iç yönergede alternatifli düzenleme yapma yetkisi vermiş ise, hem esas sözleşmede hem de iç yönergede aynı hususa ilişkin düzenleme yapılabilir. Örneğin, şirketi temsilde iki yönetim kurulu üyesinin birlikte imza atması zorunluluğuna dair hüküm hem esas sözleşmeye hem de iç yönergeye konulabilir ${ }^{112}$. Böyle durumlarda yönerge hükmünün

KIRCA/ŞEHIRALI ÇELIK/ MANAVGAT, s. 602.

ÖZSUNGUR, s. 138.

KARAHAN, s. 413.

TEKINALP, Sermaye Ortaklıkları, s. 216.

KIRCA/ŞEHIRALI ÇELIK/ MANAVGAT,, S. 605.

KARASU, s. 187.

Aksi esas sözleşmede kararlaştırılmamışsa şirketin temsili çift imza ile mümkündür. Ancak uygulamada çift imza kuralına esas sözleşme ile istisna getirilmemesine rağmen, imzaya yetkili kişilerin birbirlerine şirket adına işlem yaparken yetki verdikleri görülmektedir. Bu durumda yetki verenlerin yetki konusu işlemler için kontrol yükümlülüğünü ortadan kalkmaz. Buna paralel olarak bu tür bir yetki verme işlemi anonim şirketlerde TK anlamında temsil yetkisinin bırakılması sonucunu da doğurmaz. Bu konuda ayrıntılı bilgi için bkz. KıRCA, İsmail, 
gücü esas sözleşme hükmünün gücüne eşittir ve aynen esas sözleşme hükmü gibi uygulanır. Yönergenin esas sözleşmeden en önemli farkı ise, esas sözleşmeye göre daha kolay yolla hazırlanması, değiştirilmesi ve kural olarak üçüncü kişiler tarafından bilinmemesidir.

\subsection{3. İç Yönergenin İçeriği}

iç yönergenin içeriğinin düzenlenmesinde bir serbesti bulunmaktadır ${ }^{113}$. Ancak yönetim organizasyonunun belirlenmesi açısından usul ve esasların iç yönergede yer alması halin gereğidir.

İ̧ yönerge anonim şirketin yönetimini düzenleyecek, YK ile devir yapılan yöneticilerin görev ve yetkilerini gösterecek, görev alanlarını ayıracak ve görev tecavüzünü engelleyecektir ${ }^{114}$. Murahhas üyelik, müdür, genel müdür, CEO, CFO veya benzeri isim ve sıfatlara iç yönergede yer verilmesiyle görev yerleri gösterilmiş, iç yönergede bu sıfat ve isimlere sahip kişilerin en azından başlıca görevlerinin sıralamasıyla da yönetimin görevleri tanımlanmış olmaktadır ${ }^{115}$.

İç yönerge, her bir görev sahibinin görev ve yetkilerini ve görevin adını belirtecek ve kimin kime bağlı olduğunu, kimin kime hesap vereceğini veya kimlerin birlikte sorumlu olduğunu düzenleyecektir ${ }^{116}$. Yönetim tarafından YK'ya bilgi verilmesi YK'nın üst gözetim görevinin ifası bakımından büyük önem taşımaktadır. İç yönergede bilgi sunma konusunda hükümlerin yer alması da gerekmektedir ${ }^{117}$.

Ayrıca iç yönerge, onay sahibini içerek bilgilere yer verecektir ${ }^{118}$. Bu hükümlerin genel ve soyut olması, iç yönerge yöneticinin ismine yer verilmemesi, YK'yı ve şirketi zamanla meydana gelecek değişikliklerde iç yönergenin tekrar düzenlenmesi külfetinden kurtaracaktır. Doğru olan önce iç yönergenin düzenlenmesi, daha sonra YK'nın bu iç yönergeye göre görevli kişileri bir kararla atamasıdır ${ }^{119}$. YK'nın bu kararı, kanunda ve mevzuatta gösterilen şekilde almak zorundadır ${ }^{120}$. Aksi halde yetki devri kanuna göre yapılmadığı için YK'nın sorumluluğu devam edecektir.

Asgari içeriğe sahip olmak şartıyla iç yönergede isteğe bağlı başka hususlara da yer verilebilir ${ }^{121}$. iç yönerge şirket yöneticileri için yönetim el kitabı işlevi görebilir. Ek hususlar şirketin büyüklüğüne, halka açık olup olmamasına ve faaliyet alanlarına göre değişebiliri ${ }^{122}$.

iç yönergede asgari olarak; dayanak, amaç maddeleri, kapsam, yönetimin oluşumu, YK başkanı, başkan yardımcıları, sekreterya, toplantılar, çağrı usulü, gündem, toplantı ve karar nisapları, kararların alınması ve geçerliliği, görev ve yetkiler, komiteler, komisyonlar ve kurullar, şirketin temsiline ilişkin hususlar yer almalıdır ${ }^{123}$.

"Ticaret Şirketlerinde Birlikte Temsile Yetkili Kişilerin Birbirlerine Tek başına işlem Yapma Yetkisi Vermeleri", AÜHFD, 2008, C. 57, S. 3, s. 455 vd.

PULAŞLI, Cilt I, s. 1008

TEKINALP, Sermaye Ortaklıkları, s. 216.

KIRCA/ŞEHIRALI ÇELIK/ MANAVGAT, s. 605.

TEKINALP, Sermaye Ortaklıkları, s. 216.

KIRCA/ŞEHIRALI ÇELIK/ MANAVGAT, s. 605.

TEKINALP, Sermaye Ortaklıkları, s. 216.

KIRCA/ŞEHIRALI ÇELIK/ MANAVGAT, s. 606.

CEYLAN, s. 27.

KIRCA/ŞEHIRALI ÇELIK/ MANAVGAT, s. 606.

KIRCA/ŞEHIRALI ÇELIK/ MANAVGAT,, s. 606.

PULAŞLI, Cilt I, s. 1008. Örnek iç yönerge içeriği için bkz. PULAŞLI, Cilt I, s. 1008. 


\subsection{4. İç Yönergenin Onaylanması ve Hüküm İfade Etmesi}

İ̧ yönergenin hazırlanması ve onaylanması konusunda görevli ve yetkili organ $Y^{\prime}{ }^{\prime}{ }^{\prime}{ }^{124}$. İç yönergenin düzenlenmesi, YK'nın devredilmez ve vazgeçilmez görev ve yetkilerinin düzenlendiği $\mathrm{m}$. 375'te sayılmamasına rağmen, münhasıran YK'ya verilen devredilmez ve vazgeçilmez görev ve yetkilerdendiir ${ }^{125}$. GK, esas sözleşme (tek kişilik sermaye şirketlerinde taahhütname) ile veya alacağı bir kararla bu yetkiyi uhdesine alamaz ${ }^{126}$. Bu durumda acaba imza yetkilileri sadece YK tarafından mı atanacaktır sorusu akla gelmektedir. TEKiNALP'e göre, iç ilişkide kalan imzalar ile elektrik, su, doğalgaz aboneliğine ilişkin belgeleri imzalamaya yetkili kişiler kapsam dışında tutulmalıdır ${ }^{127}$. DOĞAN ise, ticari mümessil ya da ticari vekil veya niteliği ne olursa olsun, imza yetkisi bulunan her kişinin yönetim kurulu tarafından atanmasının gerekli olduğunu vurgulayarak, kendilerine yetki verilmiş müdürlerin, sadece imza yetkisi bulunmayan kişileri atayabilecekleri, imza yetkisini haiz kişilerin ise her hâlükârda yönetim kurulunca belirlenebileceğini belirtmektedir. Esas sözleşmeye bu konuda konulan bir düzenleme dahi geçersizdir ${ }^{128}$. AKDAĞ GÜNEY de, üst yönetimin altında yer alacak kişilerin, diğer bir ifadeyle işlemlerin icra safhası ile yetkili olanlarla birlikte temsilci ve vekillerin atanması ve azli yetkisinin münhasıran yönetim kuruluna ait olduğunu ifade etmektedir ${ }^{129}$. İsviçre Borçlar Kanununun 716a maddesinin 1. fıkrasının 4. bendinde, "şirketin idaresi ve temsili ile görevlendirilmiş kişilerin atanması ve görevden alınması" yönetim kurulunun devredilemez ve vazgeçilemez görev ve yetkileri arasında gösterilmektedir ${ }^{130}$. Yönetim kurulu bu görevi, herhangi bir üyesine devredemeyeceği gibi, üçüncü bir kişiye de devredemez.

İç yönergeyi düzenleyen YK'nın iç yönergedeki hükümlerin ne zaman hüküm ifade edeceği yönünde bir madde koyması pekâlâ mümkündür. Bu durumda iç yönerge, iç yönergenin hüküm ve yürürlük maddesine göre belirtilen zamanda hüküm ifade edecektir.

iç yönergenin tescil ve ilana tabi olmadığı hallerde YK kararının alınmasıyla hüküm ve sonuç doğuracaktır. İç yönergenin tescil ve ilana bağlı olduğu durumlarda da iç yönergenin tescil ve ilan ile hüküm ifade edeceği kabul edilemez.

\subsubsection{Devredilen Yetkinin YK'nın Devredilmez Görev ve Yetkilerinden Olmaması}

YK'nın devredilemez yetkileri m. 375'te düzenlenmiştir. Bu hüküm ile TK'da organlar arasında işlev ayrımı yapılmış, organlar arasında işlev bağlamında güç yönünden denklik kabul edilmiş, buna karşılık genel kurulun her şeye kadir olduğuna ve bütün kararları alabilme yetkisi ile donatıldığına ilişkin salt yetki teorisi reddedilmiştir. YK, Kanunun 375. maddesinde gösterilen bu yetkileri ne esas sözleşmeyle ne de bir kararla genel kurula veya kurulacak kurullara ve komitelere devredebilir. Ayrıca bu yetkilerden feragat da edemez.

Şirketin üst düzeyde yönetimi ve bunlarla ilgili talimatların verilmesi (m.375,1-a): "Üst düzeyde yönetim" ile kastedilen, genel işletme politikası başta olmak üzere, yatıım, finansman, temettü gibi politikaların hedeflerinin karara bağlanması, bunlara ulaşılması için seçilen araçların gösterilmesi, hedeflere ulaşılıp ulaşılmadığının veya ulaşılıp ulaşılmayacağının belirlenmesi, bütçe uygulamasının kontrolü ve stratejilerin tespitidir ${ }^{131}$. Politikalara ve organ olarak GK veya YK gösterilmiştir. Bu yetkinin hiçbir organ açısından o organa özgülenmiş ve devredilemeyen bir yetki olmadığı belirtilmiştir. Ancak TK'nın ruhuna aykırıdır. Çünkü YK'nın devredilemeyen ve vazgeçilemeyen yetkilerini düzenleyen n. 375, 1-a'da şirketin üst düzey yönetimi; 1-b’de ise yönetim teşkilatının belirlenmesi görev ve yetkisi düzenlenmiştir. Limited şirketler için ise bkz. m. $625,1-a, b$. ancak 625,2' de şirket sözleşmesiyle bu yetkinin GK'nın onayıyla kullanılmasına zemin hazırlayan düzenleme mevcuttur. Bu halde bile, müdürler kurulunun GK onayı ile alacağı kararlarda da, müdürler sorumlu olacaktır. Madde gerekçesi de TK m. 375'e yollama yaparak, bu konuda müdürler kurulunun görev ve yetkileri açısından YK ile özdeş olduğunun altını çizmiştir.

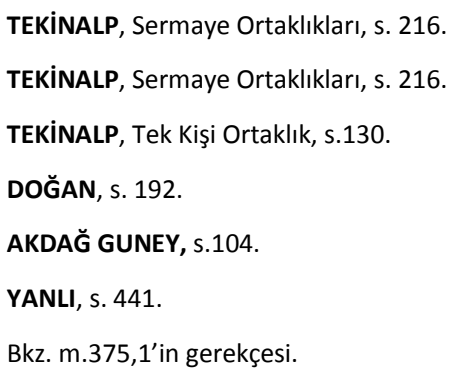


hedeflere ulaşılmasına ilişkin kararlar ve stratejilerin uygulanması ile ilgili talimatlar da yönetim kurulu tarafından verilebilir ${ }^{132}$. Talimatlar, sözlü veya yazılı olabileceği gibi bir iç yönetmelik, sirküler veya genelge ile de şekillenebilir ${ }^{133}$. Bağlı şirketlerde, üst düzeyde yönetim yetkisinin kime ait olduğu sorusu özellik gösterir. Başka bir deyişle, bağlı şirketlerin yönetim kurulları üst düzeyde yönetim yetkisini haiz midir? Yoksa bu yetki ana şirketin yönetim kuruluna mı aittir? Hükmün münferit şirketler için ön görüldüğü ne kadar açıksa, bağımsız yönetim kurullarının düşünülmüş olduğu da o kadar doğaldır. Bu hüküm, Kanunun 195 ve devamı madde hükümleri ile birlikte değerlendirilmeli, değerlendirmede 202 ilâ 204. maddeler dikkate alınmalıdır. Bağlı şirketin üst yönetimi, hâkim şirketin ve tepe şirketin üst yönetimi ile uyumlu olmalıdır. Bu ilke şirketler topluluğunun kanun tarafından tanınan gerçeğidir. Başka bir deyişle, hâkim ve özellikle tepe şirketin üst yönetimi bağı şirketleri de kapsar ve bağlar. Ancak bu sınırlamalara rağmen bağlı şirketlerde de üst yönetim devredilemez.

Şirket yönetim teşkilatının belirlenmesi (m.375,1-b): Örgüt şeması, yönetimde yer alan herkesin, altlık-üstlük ilişkilerini, görev tanımlarını; bölümleri ve aralarındaki ilişkileri gösteren şemadır. Bu hükümle, yönetim kurulunun, yönetimin bir bütün halinde işleyişini görmesi, politikaların ve stratejilerin gerçekleştirilmesinde görevlilerin rolünü değerlendirmesi; insan kaynaklarının kullanılmasını izlemesi amaçlanmıştır. Şema, sistemin işleyişindeki aksaklıkların ve aksayan yerin belirlenmesine yardımcı olur. Kurul yönetimi devrederken de zaten örgüt şemasını tayin eder. Şemada yer almayan ayrıntıyı, diğer yetkililer belirleyebilir.

Muhasebe, finans denetimi ve şirketin yönetiminin gerektirdiği ölçüde, finansal planlama için gerekli düzenin kurulması (m.375,1-c): Muhasebenin bölüm olarak belirlenmesi ile kastedilen, kanuna ve genel kabul gören muhasebe ilkelerine göre muhasebe örgütünün (bölümünün), konsolide hesap sisteminin, defter ve kayıtların tutulma kurallarının tespiti, hesap planlarının yapılması, yani, düzenin, bir anlamda muhasebe bölümünün örgütlenmesidir. Muhasebenin hangi ortamda tutulacağını da yönetim kurulu karara bağlar. Muhasebenin belirlenmesi ve programlanmasını, muhasebenin 515. maddede öngörülen dürüst resim ilkesine göre belirlenmesini de içerir. "Düzenin kurulması" sözcüğünden de anlaşıldığı üzere, devredilmez olan düzenin kurulması görevidir; yoksa muhasebenin tutulması devredilebilir ve yönetimin devri hallerinde bu husus açıkça ifade edilir. Finansal denetim düzeninin kurulması, şirketin iş ve işlemlerinin denetlenmesine ilişkin bir "içdenetim" sisteminin ve bunu yapacak örgütün (bölümün) gösterilmesidir. Şirket hangi büyüklükte olursa olsun, şirkette, muhasebeden tamamen bağımsız, uzmanlardan oluşan, etkin bir iç-denetim örgütüne gereksinim vardır. Bir anonim şirketin denetimi sadece bir bağımsız dış denetim kuruluşuna bırakılamaz. Bir bağımsız denetim kuruluşunun onlarca, hatta yüzlerce müşterisi vardır; onlara birçok hizmet sunmaktadır. Her müşterisini içerden ve yakından izleyemez. Finansal denetim, bir anlamda teftiş kurulunun yaptığı denetimdir. Finansal denetim iş ve işlemlerin iç denetimi yanında, şirketin finansal kaynaklarının, bunların kullanılması şeklinin, durumunun, likiditesinin denetimini ve izlenmesini de içerir. Finansal denetim kurumsal yönetim kurallarının gereğidir. Finansal planlama, bütçeleme ile yeterli likiditenin sağlanmasının güvence altına alınmasını ifade eder. Kurumsal yönetim kurallarının ve çağdaş yönetim usullerinin gereği olan bu örgüt bütün anonim şirketler için gerekli değildir; şirketin yönetimi gerektiriyorsa finansal planlama zorunludur.

Müdürlerin ve aynı işleve sahip kişiler ile imza yetkisini haiz bulunanların atanmaları ve görevden alınmaları (m.375,1-d): Müdürler ile aynı işleve sahip kişilerin atanmaları ve imza yetkisini haiz kişilerin seçimi yönetim kurulunun devredilemeyen yetkilerindendir. İmza yetkililerini belirlemek murahhaslar dâhil kimseye devredilemez. Bu hükümdeki 'müdürler ile aynı işleve sahip kişiler' ibaresi kendilerine yönetme görev ve yetkileri tanınmış olan kimseleri ifade eder. Görev ve yetki verilmesi ile kastedilen yönetim hakkının veya genel olarak yönetimin geçirilmesi, diğer bir ifadeyle 'delegasyon' değildir. Kastedilen, işlemlerin yürütülmesi aşamasına ilişkin yetkilerdir.

Yönetimle görevli kişilerin, özellikle kanunlara, esas sözleşmeye, iç yönergelere ve yönetim kurulunun yazılı talimatlarına uygun hareket edip etmediklerinin üst gözetimi (m.375,1-e): Üst gözetim ile kastedilen hem kuramsal açıdan hem de işletme iktisadı yönünden gerekli olan işlerin akışının gözetimidir. Yoksa yönetim

132 Bkz. m.375,1'in gerekçesi. 
kurulu bir kontrol ve denetim organı değildir. Üst gözetimin normatif niteliği hükmün bizzat kendisinden anlaşılmaktadır.

Pay, yönetim kurulu karar ve genel kurul toplantı ve müzakere defterlerinin tutulması, yıllık faaliyet raporunun ve kurumsal yönetim açıklamasının düzenlenmesi ve genel kurula sunulması, genel kurul toplantılarının hazırlanması ve genel kurul kararlarının yürütülmesi (m.375,1-f).

Borca batıklık durumunun varlı̆ında mahkemeye bildirimde bulunulması (m.375,1-g): Son yıllık bilânçodan sermaye ile kanunî yedek akçeler toplamının yarısının zararlar sonucu karşılıksız kaldığının, yani yitirilmiş bulunduğunun anlaşılması halinde, yönetim kurulu, genel kurulu hemen toplantıya çağırmaya ve uygun gördüğü gerekli önlemleri kurula sunmak zorundadır. Bu önlemler, sermaye artırımı, bazı üretim birimlerinin veya bölümlerin kapatılması ya da küçültülmesi, iştiraklerin satışı, pazarlama sisteminin değiştirilmesi vs. olabilir. Yönetim kurulunun, genel kurulu hemen toplantıya çă̆ırması, şirketin finansal yönden kötü durumda bulunduğunu bütün açıkı̆ğıyla kurula anlatması, hatta bu konuda bir rapor vermesi, zararların sebeplerini (kaynaklarını) göstermesi ve tedavi çareleri önermesi gerekir, aksi halde yönetim kurulu sorumlu olur.

\subsection{Devrin Sorumluluğa Etkisi}

TK'da yetki devri halinde müteselsil sorumluluğun uygulanmayacağı kabul edilmiştir ${ }^{134}$. Kanundan veya esas sözleşmeden doğan bir görevi veya yetkiyi, kanuna dayanarak, başkasına devreden organlar veya kişiler, bu görev ve yetkileri devralan kişilerin seçiminde makul derecede özen göstermediklerinin ispat edilmesi hâli hariç, bu kişilerin fiil ve kararlarından sorumlu olmazlar $(553,2)$. Bu düzenlemeye göre YK, yönetim yetkilerini TK m. 367 'deki şartlara uygun olarak YK üyelerine veya üçüncü kişilere devretmişse, devredilen yetkilerin kullanılmasından sadece yetkiyi kullanan murahhaslar sorumlu olur ${ }^{135}$.

İcrada görevli olmayan YK üyelerinin sorumluluğu ise bu görev ve yetkileri devralan kişilerin seçiminde makul derece özen gösterdiklerinin ve gözetim görevlerini ihlal ettikleri hallerde vardır ${ }^{136}$.

Yetki devri, kanuna veya esas sözleşmeye göre yapılmamışsa yapılan işlem geçersiz olacaktır ${ }^{137}$. Yetki devri işlemi geçersiz olduğundan sorumluluk açııından devir işlemi hiç yapılmamış kabul edilir ve geçersiz bir şekilde yapılan yetki devrine dayanarak yapılan işlemden bütün YK üyeleri müteselsil sorumludur ${ }^{138}$.

Geçerli bir şekilde yapılan yetki devri halinde, kendisine yetki devri yapılan kişinin yaptığı işlemlerden sorumluluk, işlemi yapan yöneticidedir ${ }^{139}$. Diğer YK üyelerinin sorumluluğu için m. 553,1 söz konusu değildir. Birden fazla murahhas üye varsa bunların görevleri birbirinden ayrılmışsa, bunların birbirini gözetleme

TEKiNALP, Sermaye Ortaklıkları, s. 219; KARAAHMETOĞLU, İsmail Özgün, 6102 Sayılı Türk Ticaret Kanunu'na Göre Limited Şirketin Temsili, Ankara 2014, s.165. Oysaki bu iki yetkinin bölünmesi iç ilişkiye ait olup devralan kişinin bağımsız hareket etmesi düşünülemeyeceği gibi devredenin talimat verme yetkisin devam eder. Bu iki ayrımın pratik sonucunu sorumluluk konusunda görmek mümkündür. Bkz. ARSLAN, s. 62. Bu çerçevede ilk durumda kural olarak yetkinin devri sorumluluktan kurtulma sonucunu doğururken, ikinci durumda yetkinin bölüşülmesi sorumluluğun paylaşılması anlamına gelir. Bkz. KARAHAN, s. 412.

DOĞAN, s. 267.

DOĞAN, s. 267.

TEKINALP, Sermaye Ortaklıkları, s. 219.

DOĞAN, s. 267.

DEDEAĞAÇ, Ender/SAPAN, Oğuzhan, "Anonim Şirketlerde Yönetim Kurulu ve Sorumluluğu”, Ankara Barosu Dergisi, 2013, s.89. 
yükümlülüğü olmadığı için sorumluluk yine sadece işlemi yapana aittir ${ }^{140}$. Ancak diğer YK üyelerinin genel gözetim görevi vardır ve bu yetki gereğince her bir YK üyesi icracı olmayan üye olarak murahhasları gözetlemekle görevli ve yetkilidir ${ }^{141}$. Bu yetki icracı olmayan üyeler tarafından şahsen değil, kurul halinde yerine getirilir.

YK üyelerinin, YK'nın devredilmez ve vazgeçilmez yetkilerinin devri halinde sorumluluğu devam eder. Örneğin, YK üst yönetim yetkisini devredemez ve bu yetkinin kullanılmasından dolayı sorumludur.

YK, yetki devrinde, yetkinin devredileceği kişiyi seçerken gerekli özeni göstermek zorundadır. Kanundan veya esas sözleşmeden doğan bir görevi veya yetkiyi, kanuna dayanarak, başkasına devreden organlar veya kişiler, bu görev ve yetkileri devralan kişilerin seçiminde makul derecede özen göstermediklerinin ispat edilmesi hâli hariç, bu kişilerin fiil ve kararlarından sorumlu olmazlar ${ }^{142}$.

YK'nın görevi devredeceği kişinin murahhas üye olması halinde, gözetim görevi murahhas müdürlere göre daha hafiftir ${ }^{143}$. Çünkü YK üyesi olan kişi daha önce GK tarafından bir denetlemeden geçmiştir. Buna karşılık, murahhas müdür ise YK üyesi olmadığı ve GK onayından geçmediği için YK'nın gözetim görevi üst düzeyde olmalıdır. Murahhas müdüre yetkinin devredildiği hallerde YK gerekli özeni göstermemişse murahhasla birlikte müteselsilen sorumlu olacaktır.

Yetki devrinin usulüne uygun yapıldığı hallerde, YK üyelerinin sorumluluktan kurtulması açısından m. 533,3 önemli bir düzenlemedir. Maddeye göre, "hiç kimse kontrolü dışında kalan, kanuna veya esas sözleşmeye aykırılıklar veya yolsuzluklar sebebiyle sorumlu tutulamaz; bu sorumlu olmama durumu gözetim ve özen yükümü gerekçe gösterilerek geçersiz kılınamaz". Özen yükümü, YK üyeleriyle yöneticileri kapsayacak şekilde kaleme alınmıştır. Yöneticilerin ayrıca zikredilmeleri, yönetim hakkının 367. maddeye göre devri halinde özellikle önem taşımaktadır ${ }^{144}$. Aynı şekilde murahhas/lar kendisine devredilen yetkiler açısından organ-şahıs olarak nitelendirildiği için kendisine bırakılan yetki sahasında bizzat sorumlu iken, kendisine devredilmesi mümkün olmayan yetkiler açısından YK ile birlikte gözetim görevinin gereği gibi ifa edilmemesi şartıyla sorumlu tutulacaktır $^{145}$.

Yönetim yetkisi kısmen veya tamamen devredildiği takdirde yönetimi devralanların çift işleve sahip olduğu ifade edilmektedir ${ }^{146}$. Bir başka deyişle müdür olan bir kişi açısından yönetim ve gözetim bir araya gelmiş olur. Bu, sorumluluğu değiştirmezken, güç açısından bir artış meydana getirir ${ }^{147}$. Oysaki murahhas müdüre yönetim halde YK/MK arasında bir kişiye yönetim ve temsil yetkisinin devri halinde bu kişi murahhas üye olurken bu yetkilerin adı geçen kişiler dışında bir başka kişiye devri halinde murahhas müdürlük sıfatı ortaya çıkmaktadır. Kendisine yetki devredilen kişi açısından ister murahhas üye isterse murahhas müdür olsun yetki devri konusunda bir farklılık yoktur. Buradaki ayrım bu kişilerin şirketi yönetme ve temsile yetkili olan müdürlük/YK üyeliği sıfatına sahip olup olmadıkları açısındandır. Bu yüzden murahhas müdürler şirkete karşı üçüncü kişi konumundadırlar. Eğer murahhas müdür yönetim kurulu üyesi olmaması nedeniyle görevlerinin ifa edilmemesinden doğan sorumluluk altına giremeyeceği gibi, murahhas müdürün gözetim görevi de yoktur. Tüm bu açıklamalardan sonra murahhas müdür (kendisine yetki devredilen kişi) ile şirketin YK/MK arasındaki hukuki ilişkinin belirlenmesi çok önemlidir. Murahhas üyeler ile yönetim kurulu arasında sözleşme ilişkisi olduğunu savunanlar yönetim kurulunun yetkilerinin şirket adına değil kendi adına murahhaslara devrettiklerini ifade etmektedirler. Bkz. DOĞAN s. 233. 
yetkisinin devri halinde çifte yetki sorunu ile karşı karşıya kalınmayacaktır. Banka ve sigorta şirketleri bu sistemi uygulamaktadırlar. Bu durumda kanunun gerekçesinde de ifade edildiği gibi iki organlı anlayışa olanak tanınmıştır. Sistem, üst yönetim ve şirket yönetimini birbirinden ayırdığı için güvenilir bir alt yapı oluşturmuştur ${ }^{148}$. Güç yoğunlaşması konusunu TEKiNALP ${ }^{149}$, tek kişilik şirketlerde işletmenin yönetiminin aynı zamanda YK başkanı olan pay sahibine devredilmesi halinde güçlükler ortaya çıkacak ve mal varlıklarının karışması tehlikesi baş göstereceği için eleştirmiştir. Bu yüzden anonim şirketlerde YK üyeliği ile genel müdürün aynı sıfatla birleştirilmemesi gerektiğini belirtmiştir. Yönetimin devri, kural olarak temsil yetkisinin devrini içermemektedir ${ }^{150}$. Böylelikle çifte yetkinin kümülatif şekilde artışı yönetim ve gözetim yetkisinin board sistem olarak kullanııması ile yönetim hızını ve etkinliğini azaltması riskini ortadan kaldırmış olacaktır. Ayrıca m.370,2 uyarınca temsil yetkisinin devredilmesi gerekir. Bu şekilde yönetim ve temsil birbirinden ayrılmış olacak, ikili bir sistem ortaya çıkacaktır ${ }^{151}$. Ancak önceki kanun döneminde temsil yetkisinin tek başına devri mümkün değildi ${ }^{152}$. Bir başka deyişle, temsil yetkisinin devri yönetim yetkisine mündemiçti. Aksi durumun kabulü halinde murahhas üyenin eTK m.342 anlamındaki müdürden farkı kalmayacaktı. Ancak TK m.370,2 uyarınca temsil yetkisinin murahhas müdüre devredilmesi halinde onun yanında en az bir kişinin murahhas üye olması gerçeği karşısında bu eleştirinin devam ettiği söylenebilir ${ }^{153}$. TK m.370,2'nin getirilmesi amacı, şirketin temsilini tamamen şirkete yabancı olan üçüncü kişilere bırakmamaktır ${ }^{154}$. Ancak bu hüküm gereğince yönetim yetkisi murahhas müdürlere verilip, şirketin temsili murahhas azaya verilmesi hali nasıl açıklanacaktır? Neticede her iki olasııkta da dışarıdan bir kişi şirkete tek başına yetkili değildir. Temsil yetkisinin devrinin ne şekilde yapılacağına dair bir açıklık söz konusu olmadığından yönetim yetkisinin devri hükümlerine gitme yolunu tercih etmeyi nasıl açıklayacağız? TK m.370,2'nin öngörülme amacı devredilebilen yönetim hakkını temsil yetkisi ile tamamlamaktır. Aksi takdirde murahhas üye ile murahhas müdür açısından yapmış olduğumuz organ şahıs nitelendirmesi haklı olarak yerini sadece icraya yetkili üye kavramına bırakacaktır. Gerçekten de yetkiyi devralan murahhas üyenin tek başına sorumlu olabilmesi için aynı zamanda şirketi temsile de yetkili olması gerekir ${ }^{155}$.

Mevcut sistem açısından dualist sistemin kontrol mekanizması ile yönetim ve temsil yetkisini tek bir şahısta toplamak suretiyle oluşturulan organizasyon takdire şayan olacaktır ${ }^{156}$. Alman hukukunda benimsenen yönetim ve gözetim ayrımı üzerine kurulu ikili organlı yapıya benzer bir yönetimin oluşturulması mümkün hale gelecektir. Zira yönetimin üçüncü kişilere devri ile birlikte tüm üyeler yürütme yetkisine haiz olmayan üye konumuna gelecektir. Böyle bir durumda temsilde şirketin tamamen üçüncü kişilere bırakılmaması yargısıyla çelişki oluşturacaktır. YK'nın devredilmez ve vazgeçilmez görev ve yetkilerinden olan üst düzey gözetim, talimat verilmesi ve yönetim teşkilatının belirlenmesine ilişkin görev ve yetkilerinin kapsamının tayininde YK'nın üyeleri

DOĞAN, s. 228.

TEKiNALP, Sermaye Ortaklıkları, s.219.

PULAȘLI, Genel Esaslar, s. 423. Pulașlı, TK m. 370,2'de düzenlenen temsil yetkisinin bir veya birden fazla üyeye veya üçüncü kişilere devredebilmesinde hareketle yönetim yetkisinin devri ile temsil yetkisinin devrinin birbirinde farklı olduğunu savunmaktadır. TK $\mathrm{m}$. 367' $\mathrm{nin}$ sadece yönetimin kısmen veya tamamen devrinde görev devredilen üyelere (icracı), diğerleri icracı olmayan üyeler olarak anılması söz konusu değildir. Kanaatimizce de temsil yetkisinin devri ile yönetim yetkisinin devri birbirinden farklıdır. Ancak hem temsil yetkisinin devrinde hem de yönetim yetkisinin devrinde benzer usul ve esaslar uygulanacaktır. Karşı görüş için bkz. DOĞAN, s. 114 ve 117. KARAHAN da 367'deki yönetim yetkisinin bölünmesi ve devri esaslarının temsil açısından da geçerli olduğunu savunmuştur. Bkz. KARAHAN, s. 413.

TEKINALP, s.123; AKDAĞ GÜNEY, YK, s.56.

KENDiGELEN, Abuzer, Yeni Türk Ticaret Kanunu, Değişiklikler, Yenilikler ve İlk Tespitler, İstanbul 2011, s. 258.

ARSLANLI, Halil, Anonim Şirketler, C. II-III, Anonim Şirketin Organizasyonu ve Tahviller, s.139.

BAHTIYAR, s.178.

ÇAMOĞLU, s. 274; DOĞAN, s. 275.

KENDIGELEN, s. 258 
tek başına sorumludur. Bu halde iç ilişkide şirketin karar almasında etkili olan murahhasların şirketin temsilinde de etkili olmaması düşünülemez. Bu yüzden devir müessesini iş bölümü ilkesini gerektiren düalist bir yapının veyahut buna benzer kontrol organın varlığını gerektiği söylenebilir ${ }^{157}$.

\section{SONUÇ}

Anonim şirketin temsil ve yönetim organı YK'dır. YK, şirketi iç ilişkide yönetmekte. Ayrıca YK, üçüncü kişilere ve ortaklara karşı dış ilişkide şirketi temsil etmektedir. Ancak YK'nın devredilmez ve vazgeçilmez görev ve yetkileri bir kenara bırakılırsa, YK bu yetkilerini bizzat kullanmak zorunda değildir. YK, bu görev ve yetkileri, usulüne uygun yetki devri yaptığı kendi üyeleri veya üçüncü kişiler yoluyla kullanabilir. Bu durumda yetki devri söz konusu olmaktadır. Yetki devri kural olarak sorumluluğun devri sonucunu da doğuracaktır.

Yeni TK, anonim şirketin temsil ve yönetimini birbirinden ayrı maddelerde düzenlemiştir. Yönetim, devredilmediği takdirde, yönetim kurulunun tüm üyelerine aittir (m.367,2). Ancak esas sözleşmede aksi öngörülmemiş veya yönetim kurulu tek kişiden oluşmuyorsa temsil yetkisi çift imza ile kullanılmak üzere yönetim kuruluna aittir (m. 370,1). Yönetim kurulu esas sözleşmeye konulacak bir hükümle, düzenleyeceği bir i̧̧ yönergeye göre, yönetimi, kısmen veya tamamen bir veya birkaç yönetim kurulu üyesine veya üçüncü kişiye devretmeye yetkili kılınabilir. Bu iç yönerge şirketin yönetimini düzenler; bunun için gerekli olan görevleri, tanımlar, yerlerini gösterir, özellikle kimin kime bağlı ve bilgi sunmakla yükümlü olduğunu belirler. Yönetim kurulu, istem üzerine pay sahiplerini ve korunmaya değer menfaatlerini ikna edici bir biçimde ortaya koyan alacaklıları, bu iç yönerge hakkında, yazılı olarak bilgilendirir. Ancak temsil yetkinsin devrinde YK, temsil yetkisini bir veya daha fazla murahhas üyeye veya müdür olarak üçüncü kişilere devredebilir. En az bir yönetim kurulu üyesinin temsil yetkisini haiz olması şarttır.

Yönetimin devrinde açıkça düzenlenmesi gerektiği belirtilen iç yönergenin, temsil yetkisinin devrinde hiç bahsedilmemiş olması büyük bir eksikliktir. Temsil yetkisinin devrine ilişkin düzenlemelerin iç yönergede bulunması herhangi bir sorun yaratmayacaktır. Bir başka deyişle, hem temsil hem de yönetim işleri iç yönerge ile devredilecektir.

6552 s. Kanun ile TK m.371'e eklenen 7. fıkra ile yönetimin devri kapsamında bir yönerge ile icracı olmayan YK üyelerinden bazılarına veya şirkete hizmet akdi bağlı olanlara yönetimin devrine ilişkin düzenlemenin sorumluluk hukukuna yansıması sorun oluşturacaktır. Fıkranın uygulanması halinde de YK üyeleri müteselsil sorumlu olacaklardır. Bu hükmün aşılması noktasında üç kişiden oluşan bir YK'da iki icracı üye varsa, diğer üyeye sınırlı yetkili ticari temsilci sıfatı tanınacak, o kişiye yönetim yetkisine giren konularda temsil yetkisi de verilecek ve bu hususlar iç yönergeye dercedilecektir. YK'nın üst gözetim sorumluluğu devam ettiği için yine de YK sorumluluktan kurtulamayacaktır. İ̧̧ yönergeyle kendisine görev verilen YK üyesi murahhas seviyesine getirilmiş olsa, murahhasların birbirini denetleme ve gözetme sorumluluğu olmadığı için o konuda yetki ve sorumluluk murahhasık verilen kişiye ait olacaktır. Bu şekilde YK müteselsilen sorumluluktan kurtulacaktır.

\section{KAYNAKÇA ${ }^{*}$}

AKDAĞ GÜNEY, Necla, "6552 Sayılı Torba Kanun Ile TTK m. 371'e Eklenen Yedinci Fıkraya iliş̧kin Değerlendirmeler", (Arslanlı Bilişim Arşivi), www.arslanlibilisimarsivi.com-01.10.2015.

AKDAĞ GÜNEY, Necla; Anonim Şirket Yönetim Kurulu Üyelerinin Hukuki Sorumluluğu, İstanbul 2010, (YK).

ALTAY, Anlam; Anonim Ortaklıkta Yönetim Yetkilerinin Devrinin Sorumluluğa Etkileri, İstanbul 2011.

ARASLI, Utkan, "Ticaret Şirket Organlarının iş Kazasından Kaynaklanan Hukuksal ve Cezai Sorumluluğu”, Çimento İsveren Dergisi, Temmuz 2010, s. 26-36.

DOĞAN, s.171; KARAAHMETOĞLU, s.171.

Aynı yazarın birden fazla eserine yapılan atıfları ayırmak için kullanılan kısaltmalar, ilgili eserin sonunda parantez içinde verilmiştir. 
ARKAN, Sabih; Ticari Işletme Hukuku, 19. Baskı, Ankara 2014

ARSLAN, İbrahim; Anonim Şirketlerde Yönetim Yetkisinin Sınırlandırılması, Konya 1994.

ARSLANLI, Halil; Anonim Şirketler, C. II-III, Anonim Şirketin Organizasyonu ve Tahviller, İstanbul 1960.

BAHTiYAR, Mehmet; Ortaklıklar Hukuku, 8. Bası, İstanbul 2014.

BOZKURT, Tamer; Şirketler ve Kooperatifler Hukuku, 6. Baskı, İstanbul 2012.

ÇAMOĞLU, Ersin; Anonim Ortaklık Yönetim Kurulu Üyelerinin Hukuki Sorumluluğu, İstanbul 2010.

DEDEAĞAÇ, Ender/SAPAN, Oğuzhan, “Anonim Şirketlerde Yönetim Kurulu ve Sorumluluğu”, Ankara Barosu Dergisi, 2013, s. 3-112.

DOĞAN, Fatih Beşir; Anonim Şirket Yönetim Kurulunun Organizasyonu ve Yönetim Yetkisinin Devri, 2. Baskı, İstanbul 2011.

GÜNDOĞDU, Gökmen/KAPLAN, Hasan, “Anonim Ortaklık ile Iş̧̧i Arasındaki Ilişkide Yönetim Kurulu Üyesinin Hukuki Durumu”, iüHFM, C.LXV, S. 2, 2007, s. 253-274.

HACıMAHMUTOĞLU, Sibel; AT ve Türk Hukukunda Anonim Ortaklığın Karar Alma Sürecinde Yönetim Kurulunun Yapısı ve Çalışanları Katılımı, Ankara 2008.

KARAAHMETOĞLU, İsmail Özgün; 6102 Sayılı Türk Ticaret Kanunu'na Göre Limited Şirketin Temsili, Ankara 2014.

KARAHAN, Sami; Şirketler Hukuku, Güncellenmiş 2. Baskı, Konya 2013.

KARASU, Rauf, "6102 Sayılı Türk Ticaret Kanunu Ile Anonim Şirketlerde Kurumsal Yönetim Ile Illgili Getirilen Yenilikler", iüHFD, C. 4, S. 2, 2013, s. 33-60. (Kurumsal Yönetim).

KARASU, Rauf; Türk Ticaret Kanunu Tasarısına Göre Anonim Şirketlerde Emredici Hükümler ilkesi, Ankara 2009. (Emredici Hükümler).

KARAYEL, Mete/DOĞAN, Mesut, "Yönetim Kurulunda Cinsiyet Çeşitliliği ve Finansal Performans ilişkisi: BiST 100 Şirketlerinde Bir Araştırma", Süleyman Demirel Üniversitesi, iiBF Dergisi, C. 19, S. 2, s. 75 vd.

KENDigelEN, Abuzer; Yeni Türk Ticaret Kanunu, Değişiklikler, Yenilikler ve Illk Tespitler, İstanbul 2011.

KIRCA, İsmail, "6102 Sayılı Türk Ticaret Kanununda Anonim Şirket Yönetim Kurulu-Başlıca Değişiklikler”, EÜHFD, C. XVI, S. 3-4, Aralık 2012, (Başlıca Değişiklikler).

KIRCA, İsmail, "Ticaret Şirketlerinde Birlikte Temsile Yetkili Kişilerin Birbirlerine Tek Başına İşlem Yapma Yetkisi Vermeleri", AÜHFD, 2008, C. 57, S. 3, s. 455 vd. (Birlikte Temsil).

KIRCA, İsmail, "TTK m. 371.7 Hakkında Bir Inceleme: AB'ye Üyelik Yolunda Geri Adım”, BATIDER, C. XXX, S. 3, 2014, (TTK m. 371.7 Hakkında). KIRCA, İsmail/ŞEHiRALi ÇELiK, Feyzan Hayal/ MANAVGAT, Çağlar; Anonim Şirketler Hukuku Cilt 1, Ankara 2013.

ÖZDAMAR, Mehmet, "6552 Sayılı Kanun Ile TTK'da Yapılan Değişiklikler Çerçevesinde Anonim Şirketin Temsili”, GÜHFD, C. XVIII, Y. 2014, S. 3-4, s. 137-164.

ÖZKORKUT, Korkut; Türk Hukukunda Bağımsız Yönetim Kurulu Üyeleri, Ankara 2007.

ÖZSUNGUR, Fahri, "Ticaret Sicilinde Tescil ve Ilanın Etkileri Sorunu", süHFD, C. 22, S. 2, 2014, s. 138

PULAŞLI, Hasan; 6102 sayılı Türk Ticaret Kanununa Göre Şirketler Hukuku Şerhi, C. I, Ankara 2011, (Cilt I).

PULAŞLI, Hasan; 6102 Sayılı Türk Ticaret Kanununa Göre Yeni Şirketler Hukuku Genel Esaslar, Ankara 2012, (Genel Esaslar).

TEKINALP, Ünal; Sermaye Ortaklıklarının Yeni Hukuku, İstanbul 2013, (Sermaye Ortaklıkları).

TEKINALP, Ünal; Yeni Anonim ve Limited Ortaklıklar Ile Tek Kişi Ortaklığın Esasları, İstanbul 2012, (Tek Kişi Ortaklık).

TOKSOY REYMAN, Berna, “Üst Yönetimde Kadın Temsili: Avrupa Birliği ve Türkiye'deki Gelişmeler", http://www.tusiad.org.tr/bilgimerkezi/fikir-ureten-fabrikadan/ust-yonetimde-kadin-temsili--avrupa-birligi-ve-turkiyedeki-gelismeler/- 03.10.2015.

ÜÇıŞıK, Güzin/ ÇELiK, Aydın; Anonim Ortaklıklar Hukuku, I. Cilt, Ankara 2013.

YANLI, Veliye, “Anonim Şirketlerde Imza Yetkilileri Sadece Yönetim Kurulu Tarafından Mı Atanabilir?”, iÜHFM, C. LXXI, S. 2, 2013, s. 439-448. 